\title{
A Review on Nanopesticides for Plant Protection Synthesized Using the Supramolecular Chemistry of Layered Hydroxide Hosts
}

\author{
Syazwan Afif Mohd Zobir 1,2,*, Asgar Ali ${ }^{3}$ (D) Fariz Adzmi ${ }^{2}$, Mohd Roslan Sulaiman 4 \\ and Khairulmazmi Ahmad 1,2,*(D)
}

check for updates

Citation: Zobir, S.A.M.; Ali, A.; Adzmi, F.; Sulaiman, M.R.; Ahmad, K. A Review on Nanopesticides for Plant Protection Synthesized Using the Supramolecular Chemistry of Layered Hydroxide Hosts. Biology 2021, 10, 1077. https://doi.org/ 10.3390/biology10111077

\section{Academic Editors: Maria}

Doroteia Campos and Maria do Rosário Félix

Received: 16 September 2021

Accepted: 11 October 2021

Published: 21 October 2021

Publisher's Note: MDPI stays neutral with regard to jurisdictional claims in published maps and institutional affiliations.

Copyright: (c) 2021 by the authors. Licensee MDPI, Basel, Switzerland. This article is an open access article distributed under the terms and conditions of the Creative Commons Attribution (CC BY) license (https:/ / creativecommons.org/licenses/by/ $4.0 /)$.
1 Department of Plant Protection, Faculty of Agriculture, Universiti Putra Malaysia, Serdang 43400 UPM, Selangor, Malaysia

2 Institute of Plantation Studies, Universiti Putra Malaysia, Serdang 43400 UPM, Selangor, Malaysia; farizadzmi@upm.edu.my

3 Centre of Excellence for Postharvest Biotechnology (CEPB), School of Biosciences, University of Nottingham Malaysia, Jalan Broga, Semenyih 43500, Selangor, Malaysia; Asgar.Ali@nottingham.edu.my

4 Department of Science and Biomedicine, Faculty of Medicine and Health Sciences, Universiti Putra Malaysia, Serdang 43400 UPM, Selangor, Malaysia; mrs@upm.edu.my

* Correspondence: syazwanafif@upm.edu.my (S.A.M.Z.); khairulmazmi@upm.edu.my (K.A.); Tel.: +601-2631-2550 (K.A.)

Simple Summary: Nanoscience and nanotechnology offer a new life for conventional pesticides with superior qualities by virtue of the physicochemical properties of the nanosized materials. These properties will improve bioavailability through different kinetics, mechanisms and pathways on their target organisms; enabling them to properly bypass biological and other unwanted resistances and therefore increase plant disease control efficacy. Inorganic two-dimensional (2D) layered hydroxides and layered double hydroxides were used as hosts, to act as functional nanocarriers for the delivery of various pesticides in combating various pests and diseases, in order to aid plant protection. This leads toward a new generation of more effective agrochemicals which are safe to life, humans and the environment.

Abstract: The rapid growth in the human population has triggered increased demand for food supply, and in turn has prompted a higher amount of agrochemical usage to meet the gaps between food production and consumption. The problem with conventional agro-nanochemicals is the reduced effectiveness of the active ingredient in reaching the target, along with leaching, evaporation, etc., which ultimately affect the environment and life, including humans. Fortunately, nanotechnology platforms offer a new life for conventional pesticides, which improves bioavailability through different kinetics, mechanisms and pathways on their target organisms, thus enabling them to suitably bypass biological and other unwanted resistances and therefore increase their efficacy. This review is intended to serve the scientific community for research, development and innovation (RDI) purposes, by providing an overview on the current status of the host-guest supramolecular chemistry of nanopesticides, focusing on only the two-dimensional (2D), brucite-like inorganic layered hydroxides, layered hydroxide salts and layered double hydroxides as the functional nanocarriers or as the hosts in smart nanodelivery systems of pesticides for plant protection. Zinc layered hydroxides and zinc/aluminum-layered double hydroxides were found to be the most popular choices of hosts, presumably due to their relative ease to prepare and cheap cost. Other hosts including $\mathrm{Mg} / \mathrm{Al}-$, $\mathrm{Co} / \mathrm{Cr}-, \mathrm{Mg} / \mathrm{Fe}-, \mathrm{Mg} / \mathrm{Al} / \mathrm{Fe}-, \mathrm{Zn} / \mathrm{Cr}-$ and $\mathrm{Zn} / \mathrm{Cu}-\mathrm{LDH}$ were also used. This review also covers various pesticides which were used as the guest active agents using supramolecular host-guest chemistry to combat various pests for plant protection. This looks towards a new generation of agrochemicals, "agro-nanochemicals", which are more effective, and friendly to life, humans and the environment. 
Keywords: supramolecular chemistry; host-guest; nanopesticides; layered hydroxides; layered double hydroxide

\section{Introduction}

Agrochemicals are multi-billion-dollar businesses for both the upstream and downstream agroindustries [1], not only providing significant employment to the population but also providing important solutions in food security and other agro-related industries. Unfortunately, attached to these industries are long- and short-term unwanted consequences, such as toxicities to nontarget crops and the users, life and environmental threats due to leaching and uncontrolled applications of the agrochemicals [2-4].

The demand for agrochemicals grows year by year due to the direct increase of food demand, which is in turn due to the high population, or due to indirect factors such as climate change, pesticide resistance, etc. This can be overcome by producing a new generation of safer agrochemicals which are life, user and environmentally friendly, by understanding their mechanism of actions, dose-cytotoxicity relationship, translocation mechanisms and omics behavior so that the nature of soil-plant-nanoparticle interactions are fully understood [5].

Nanoscience and nanotechnology based on different disciplines and combined with precision farming can offer a holistic solution for more effective and precise tools for diagnosis, treatment and pest-management control in the modern agricultural sector [6]. The understanding of nanoscience and nanotechnology enables us to increase agrochemical efficacy and reduce the amount used, reduce the frequency of application, minimize nutrient or active-ingredient losses and also improve plant tolerance to various biotic stresses such as drought, heat, and salt [7], and hence optimize the input-output balance of the agricultural products.

For crop protection and management, nanomaterials can be used as efficient delivery agents for various pesticides; insecticides, herbicides, fungicides, defoliant, biocides, etc., and can help us move towards economically viable and ecofriendly agrochemicals [8]. With their controlled release and targeted delivery, this new generation of pesticides can improve the bioavailability of the active ingredients and therefore increase their efficacy compared with their counterparts [9]. Furthermore, in the long run, the updated regulations and safety of current pesticides and their nanoproducts are necessary to protect humankind and the environment.

Over the years, the advantages of nanotechnology applications in agriculture, especially for pesticides, have been uncovered, as shown by the growing trend in research, development and innovation (RDI). Therefore, this review will discuss the use of host-guest supramolecular chemistry for plant disease protection. Due to the intense development that has been made in this area of RDI, we only focus our review on the layered hydroxides and layered double hydroxides as the hosts and various types of pesticides as the guests or active ingredients (AI). In addition, the synthesis methods, kinetics and mathematical models and characterization techniques together with their controlled-release properties are briefly discussed. Moreover, a discussion on the RDI of nanopesticides, especially considering their conventional active ingredients, will also be included in this review.

To the best of our knowledge, no specific review focusing on host-guest supramolecular chemistry using various layered hydroxides as the hosts is available in the open literature. Therefore, it is hoped that this review will fill the gap and serve to update the current advancements in this area of RDI, where nanoscience and nanotechnology coupled with green technology [10] are used for holistic pest management, especially for plant protection.

This review aims to compile and update the current trends and advancements of the next generation of agrochemicals, in particular, the agro-nanofungicides. The manuscript covers the definitions, chemical structures, applications, their synthesis routes and physic- 
ochemical characterizations. In addition, some basic principles for their formation, and finally the advancement of the current RDI of these types of agro-nanofungicides for plant protection are also included.

This review also aims to give a general overview of the use of host-guest supramolecular chemistry for the synthesis of fungicide nanodelivery systems, nanopesticides, their advantages and limitations. Due to too many hosts that can be possibly used for this purpose, we confine our review to only the layered hydroxides and layered double hydroxides as the hosts, and various types of fungicide active ingredients as the guests. The following keywords were used in this search: layered hydroxides and/or layered double hydroxides together with either pesticides, antimicrobials, insecticides, fungicides, herbicides, disinfectants, defoliants, and plant growth regulators. The majority of the references are from the recent publications, within the last 5 years, where the RDI in this area is more intense, however, the pieces of literature available before this period will be also included if they are of some help, so that the content of the paper reflects a general overview of the use of layered hydroxides and layered double hydroxides for pesticide nanodelivery systems.

\section{Commercially Available Nanoproducts for Agriculture Applications}

Various applications of nanotechnology for the agriculture sector have been researched and developed either for their direct or indirect uses, to improve stress tolerance, prolong the shelf life of crop products, etc. These include agro-nanochemicals for fertilizer, soil enhancer, plant protection and management, precision farming, sensors and detection, pesticide remediation, animal production, postharvest management, etc. Among the most active countries in promoting agro-nanotechnology products are India, Germany, UK, USA, Vietnam, Taiwan, Brazil, China, Malaysia and the Netherlands [11].

As a result, more than 230 nanoproducts of 37 types for various agriculture applications were introduced into the global market from 75 companies of 26 countries for animal husbandry, fertilizers, plant breeding, soil improvement and plant protection. The latter includes algaecides, herbicides, biocides, disinfecting agents, fumigants, etc. Among the notable manufacturers are Neufarm GmbH, Plant Vitality Ltd., Kanak Biotech, FRAmelco, Aqua-Yield Hub, Organic Fertilizing, Reed Mariculture Inc, Prodotti Arca S.r.l, Kimitec Group, Richfield Fertilisers Pvt, Blue Planet Environmental, Danaflex Nano, Bioteksa, AgriLife, NanoL and Baltic, Vive Crop Protection, DVS BioLife Ltd., Samarita, and Litho Plant [11]. Examples of nanofertilizer manufacturers are given elsewhere [8]. A list of commercially available nanoproducts and their economic viability can be found elsewhere [12].

\section{Pesticides: Definition, Classifications and Demand}

\subsection{Definition}

Based on the United States Environmental Protection Agency (EPA), a pesticide is defined as any substance or a mixture of substances intended for (i) preventing, destroying, repelling, or mitigating any pest; (ii) plant regulation, defoliant, or desiccant; and (iii) use as a nitrogen stabilizer. Pesticides are usually composed of an active ingredient (AI) to prevent, destroy, repel, or mitigate a pest, or is a plant regulator, defoliant, desiccant, or nitrogen stabilizer. Together with the AI are inert ingredients (II), which are important for product performance and usability.

Many databases have described the basic and other information about AI for pesticides, such as IUPAC, EU, etc. These can be found on their homepages. In addition, a review of the ecotoxicological and regulatory aspects of environmental sustainability of nanopesticides can be found elsewhere $[13,14]$.

\subsection{Classifications}

Pesticides can be grouped under chemical and nonchemical or biopesticides. The former can be organic or inorganic and are classed as Ia, Ib, II, III and U according to their toxicity, indicating extremely hazardous, highly hazardous, moderately hazardous, 
slightly hazardous and unlikely to present an acute hazard, respectively. This is based on a comprehensive classification of pesticides that can be found on the WHO homepage [15].

The IUPAC pesticides properties database (PPDB) is another comprehensive pesticide database on the chemical identity, physicochemical, human health and ecotoxicological data can be found at the Agriculture \& Environment Research Unit (AERU) at the University of Hertfordshire, for a variety of end users to support risk assessments and risk management [16]. Similar to that, the European Union (EU) also has a comprehensive pesticides database which can be accessed [17]. Based on the National Pesticides Information center (NPIC) pesticides are classified according to their target use as given in Table 1 [18].

Table 1. Types of pesticides based on the National Pesticides Information Center [18].

\begin{tabular}{cl}
\hline Pesticide & \multicolumn{1}{c}{ Target/Use } \\
\hline Algaecides & Killing and/or slowing the growth of algae. \\
Antimicrobials & Controlling germs and microbes such as bacteria and viruses, etc. \\
Biopesticides & Made of living things, come from living things, or are found in nature. \\
Desiccants & Drying up of living plant tissues. \\
Defoliants & Causing of plants to drop their leaves. \\
Disinfectants & Controlling of germs and microbes such as bacteria and viruses \\
Foggers & Killing of insects that are in the open and touch the pesticides. \\
Fungicides & Control of fungal problems such as molds, mildew, and rust. \\
Herbicides & Killing or inhibiting the growth of unwanted plants, aka weeds. \\
Insecticides & Insect control. \\
Insect growth regulators & Disrupting the growth and reproduction of insects. \\
Miticides & Control of mites that feed on plants and animals \\
Molluscicides & Control of slugs, snails and other mollusks. \\
Mothballs & Killing of fabric pests by fumigation in sealed containers. \\
Ovicides & Control of pests using things found in nature, or manmade versions of things found in nature. \\
Pheromones & Control of eggs of insects and mites. \\
Natural and Biological Pesticides & Biologically active chemicals which are used to attract insects or disrupt their mating behavior. \\
Plant & The ratio of chemicals in the mixture is often species-specific. \\
Repellents & Altering the growth of plants. For example, they may induce or delay flowering. \\
Rodenticides & Repelling unwanted pests, often by taste or smell. \\
Synergists & Killing of rodents such as mice, rats, and gophers. \\
& Make certain pesticides more effective, but they are not effective when used alone \\
\hline
\end{tabular}

\subsection{Demand}

Agrochemicals are important for the agricultural sector, involving multi-billion-dollar businesses of various multinational companies in developed and developing countries. This is due to the rapid growth in demand, triggered by various factors especially the growing food demand due to rapid growth of the human population, less efficiency of the input-output balance of the food products, climate factors, etc.

The global demand for agrochemicals was estimated at a value of USD 208.6 billion in 2020, and this value is projected to reach USD 246.1 billion by 2025, at a CAGR of $3.4 \%$ during the forecast period. The fungicides group contributes about $9 \%$ with a value of USD 18.7 billion and is projected to reach a value of USD 24.5 billion by 2025, growing at a CAGR of $4.6 \%$ during the forecast period [1]. The agrochemicals in this category include pesticides (herbicides, insecticides, fungicides), fertilizers (nitrogenous, phosphatic and potassic) and crop application (Cereals \& Grains, Oilseeds, Fruits \& Vegetables). Herbicidebased agrochemicals contribute the highest demand in the agrochemical sectors due to their convenient use in economical crops such as sugarcane, rice, soybean, oil palm, rubber, cotton, etc.

Bayer and BASF (Germany), Yara International (Norway), Compass Minerals (USA), Syngenta (Switzerland) and Adama Ltd. (Israel) are some of the global players in the agrochemical industry [1]. 


\section{Nanomaterials: Definition and General Properties for Nanotechnology Applications}

As mentioned earlier, many types of nanopesticides can be generated from various types of nanomaterials; 0D, 1D, 2D and 3D. These including chitosan nanoparticles, various types of carbon nanostructures such as graphene and its derivatives, carbon nanotubes, carbon nanodots, etc. In addition, micelles, chitin, clays, clay derivatives and synthetic clays, activated carbon, zeolites, silica, etc., have also been used for the formation of host-guest nanopesticides.

\subsection{Definition}

Based on ISO/TS 80004, nanomaterials are defined as "the materials with any external dimension in the nanoscale or having an internal structure or surface in the nanoscale", with nanoscale defined as the "length range approximately from $1 \mathrm{~nm}$ to $100 \mathrm{~nm}$ ". This includes a discreet piece of material (nano-objects) and materials with internal or surface structure on the nanoscale (nanostructured) [19].

Based on the dimension, nanomaterials can be categorized into 0D, 1D, 2D and 3D. Fullerenes, carbon nanodots, quantum dots, are some examples of OD nanomaterials. Carbon nanotubes (CNT), nanofibers, etc., are 1D, and clays, synthetic clays, layered hydroxides and layered double hydroxides, layered triple hydroxides, graphene and its derivatives are some examples of nanomaterials of the 2D family. Activated carbons, zeolites and metal-organic frameworks (MOF) are some examples of the 3D family.

\subsection{General Properties of Nanomaterials}

Nanomaterials have superior quality compared to their bulk counterparts' higher strength and higher surface area to volume ratio, chemical reactivity and conductivity, etc. Products based on nanotechnology are produced due to one or more of these superior properties, and lately are visible in many sectors including agriculture, etc., as discussed earlier. This is due to the belief and proof that these types of products could improve quality of life, either directly or indirectly.

For engineered nanomaterials, their physicochemical properties are usually attached to the general superior properties together with the intended specific properties. For example, due to the high specific surface area, more guests can be loaded onto the surface, and due to the intercalation and deintercalation properties of the guests, ion exchange can take place, resulting in slow- or controlled-release properties of the guests of the host-guest nanomaterials. This will be discussed later.

\subsection{Toxicity of Nanomaterials}

Human beings, animals, plants, and other living organisms, etc., and the environment, are subjected to various nanomaterial exposures from different kinds of their origins; engineered, natural and incidental, from time to time. With the advancement of nanotechnology, especially with new types of engineered nanomaterials being intensely synthesized, there is sometimes a threat to life. Therefore, nanotoxicology; the study of the toxicity of nanomaterials to life and the environment, is equally important, in tandem with the advancement of nanotechnology [20,21].

Previous works have shown that nanofungicides based on Zn/Al-LDH were found to be more potent and safer for seeds and seedlings, compared with their counterparts. In addition, the presence of cations such as zinc from the host improves the growth of the seedling [9]. Similarly, the cytotoxicity, genotoxicity and cell death assays of chitosanbased fungicide nanoparticles did not reveal any cytotoxicity or genotoxicity potential [22] Although many other previous works have also indicated that encapsulation of pesticides generally reduces their toxicity, this cannot be easily generalized to other nanopesticides. Therefore, research, development and innovation (RDI) in nanotoxicology is as important as its nanotechnology counterparts [23-25]. 


\subsection{Nanomaterials for Agricultural Practices}

Nanomaterial is one of the bases for various nanotechnology applications due to their superior physicochemical properties as mentioned earlier. Together with nanoscience, their physicochemical properties can be engineered to tailor their requirements for various technological applications in various fields which demanded the multidisciplinary kind of RDI.

As previously mentioned, one of the most important nanotechnology applications is in the agricultural sector, including pesticides for plant protection. Due to very diverse nanomaterials that can be used for the generation of new nanopesticides, here we focus our review only on the layered hydroxides; layered hydroxide salts and layered double hydroxides. This is due to their special reversible intercalation and deintercalation process, their 2D inorganic layered structure enables them to host various active ingredients, the pesticide active agents. By the virtue of the ion exchange properties of the host-guest complex, these properties have been exploited for the controlled-release formulation of pesticides. This will be discussed later.

\section{Layered Hydroxides}

Layered compounds are composed of two-dimensional units connected to each other by weak forces. Layered hydroxide salts (LHS) with a general formula of $\mathrm{M}^{2+}(\mathrm{OH})_{2-x}$ $\left.\left(\mathrm{A}^{\mathrm{m}-}\right)_{\mathrm{x}} / \mathrm{m} \cdot \mathrm{nH}_{2} \mathrm{O}\right)$ and layered double hydroxides $(\mathrm{LDH})$ with the general formula of $\left.\mathrm{M}^{2+1-\mathrm{x}} \mathrm{M}^{3+\mathrm{x}}(\mathrm{OH})_{2}\left(\mathrm{~A}^{\mathrm{m}-}\right)_{\mathrm{x} / \mathrm{m}} \cdot \mathrm{nH}_{2} \mathrm{O}\right)$ are layered compounds, where the $2 \mathrm{D}$ inorganic metal hydroxides sheets are stacked together by weak forces.

Layered hydroxides and layered double hydroxides are examples of 2D layered materials in this family. The former has the brucite-like structure, where the inorganic layer is composed of only one cation $\left(\mathrm{M}^{2+}\right)$ such as $\mathrm{Mg}$ or $\mathrm{Zn}$, etc., while for the latter, the inorganic layer is composed of at least two cations; $\mathrm{M}^{2+}$ and $\mathrm{M}^{3+}$, such as $\mathrm{Mg}$ with $\mathrm{Al}, \mathrm{Zn}$ with Al, etc. (Figure 1). Due to its positively charged inorganic layers, counter anions are intercalated in between or interlayer of the 2D layered structure to keep the material neutrally charged. This anion can be exchanged with various anions for various applications, especially for agrochemicals such as pesticides, fungicides, etc.

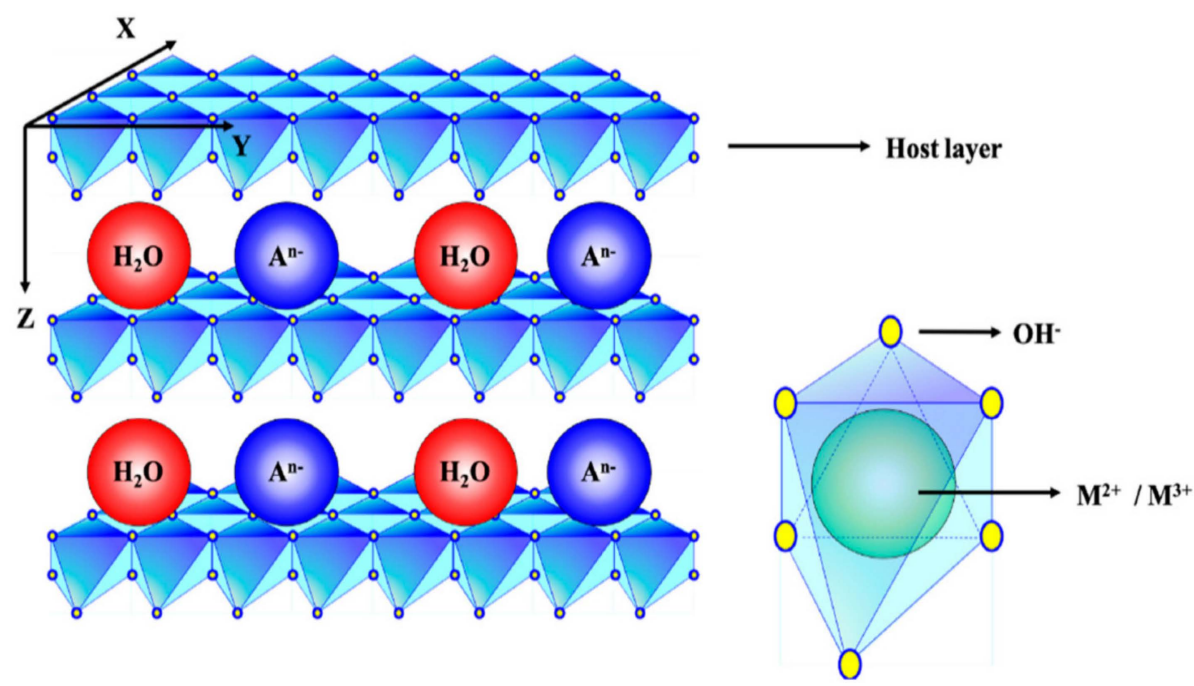

Figure 1. The structure of $\mathrm{LDH}$ is composed of a 2D, inorganic, brucite-like structure. Layered hydroxide has a similar structure, but only composed of $\mathrm{M}^{2+}$ instead of $\mathrm{M}^{2+} / \mathrm{M}^{3+}$ in the $\mathrm{LDH}$. The counter anion, $\mathrm{A}^{\mathrm{n}-}$ together with water molecules are present in the inorganic interlayer [26].

Layered hydroxides (LHs) and layered double hydroxides (LDHs) are widely used for the formation of a new generation of agrochemicals and other uses related to agriculture, based on nanotechnology platforms. As shown in Figure 1, these two families of LHs and 
LDHs are used to synthesize smart fertilizers, nanosensors, precision farming, pesticide remediation, nanopesticides and other uses, either directly or indirectly.

The 2D, inorganic, layered structure is composed of single or double metal ions. The thickness of this inorganic layer is well established to be $4.8 \mathrm{~A}$. The basal spacing of the LDH with nitrate, sulfate, carbonate, chlorine and iodine is around 7-9 A, depending on the counter anion occupied in the interlamellar of the LDH [27]. Upon intercalation of the guest anions such as pesticides, drugs, etc., this basal spacing will be expanded, depending on the size and spatial orientation of the anions in the interlamellar of the LDH [28].

Various active ingredients, anions, organic and inorganic species can be intercalated in the LDH interlamellar as the guests using the supramolecular chemistry approach. As a result, various applications can thus be generated. The nanostructured LDH has been used as the host of the AI, and the resulting complex inherited superior properties of the host; controlled release, being more potent, having higher bioavailability, etc. [9].

\subsection{Application of Layered Hydroxides}

LHs and LDHs are composed of positively charged inorganic layers (Figure 1), and the counter anion can be replaced by various AIs for various purposes as shown in Figure 2. These include nanopesticides for plant protection [29], drug delivery [30] and gene delivery [31], sunscreen protection [32], catalysis [33] and environmental remediation, [34], supercapacitors [35], cosmetics [36], etc. If drugs or therapeutic agents are intercalated into the interlayers, various nanodrugs [37], or nanotherapeutic delivery systems can be generated which are useful for anticancer purposes [38], anti-TB purposes [39], etc. By virtue of the ion-exchange properties or dissolution of the inorganic brucite-like layers (or both), the intercalated AIs can be released from their hosts-LHs or LDHs-resulting in the controlled-release properties and will be discussed in Section 5.2.

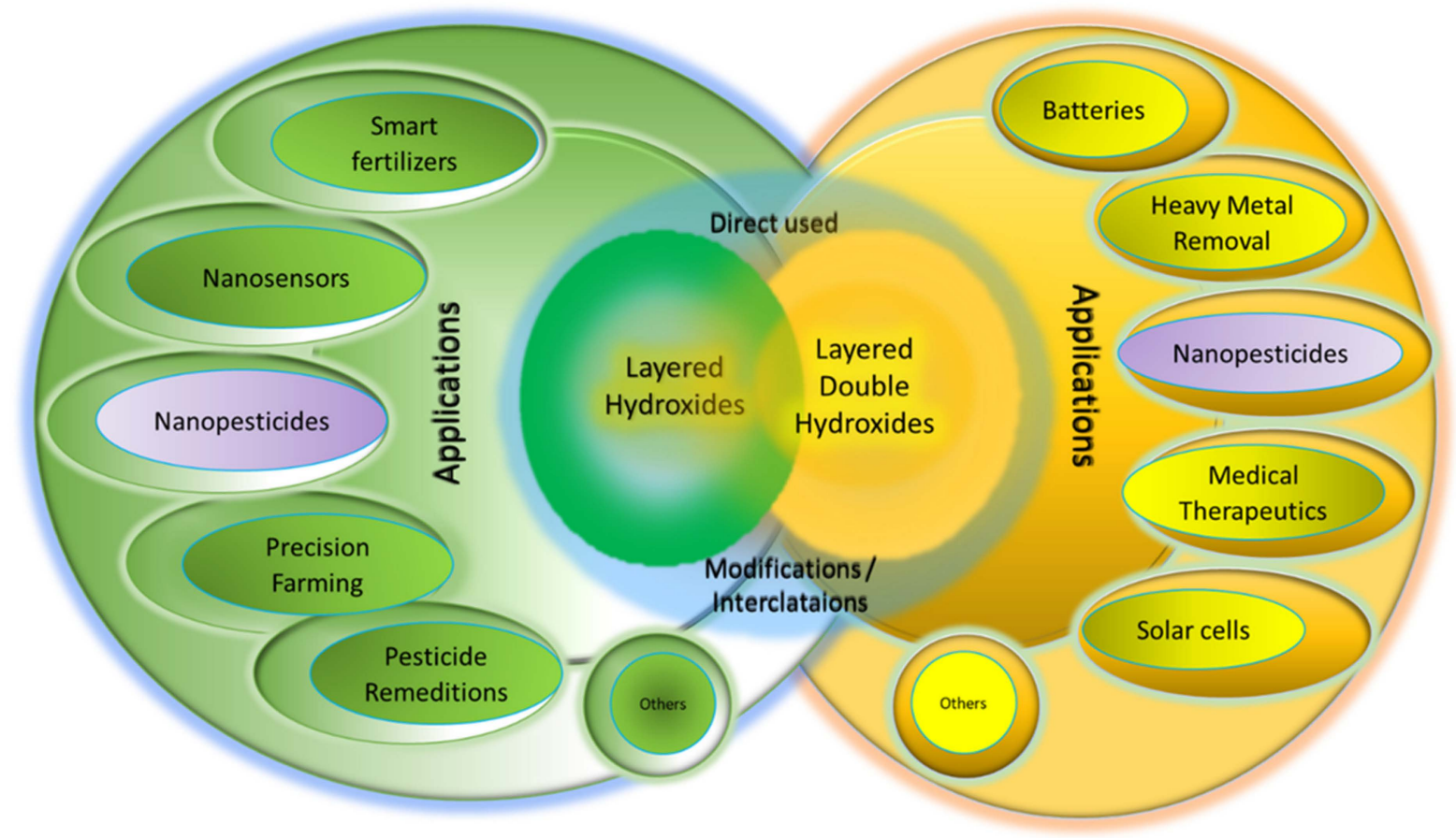

Figure 2. Various technological applications of LHs and LDHs either as they are or after modification by intercalation of AIs using the host-guest supramolecular chemistry approach.

As mentioned earlier, LHs and LDHs are composed of inorganic, brucite-like structures which, upon calcination at a certain temperature, result in the collapse of the 2D layered structure and subsequently generate various single or mixed oxides, respectively. This results in a uniform distribution of oxide which is useful for catalyst [33] purposes. Due to their high ion-exchange capacity, LDHs can be used for the remediation of heavy-metal- 
contaminated or pesticide-contaminated water [34]. Other applications, including smart fertilizers, nanosensors, etc., are shown in Figure 2.

\subsection{Application of Layered Hydroxides in Agriculture}

Various applications of layered hydroxides in agriculture are summarized in Figure 3; smart fertilizers, nanosensors, pesticides remediations, precision farming, nanopesticides, etc. LHs and LDHs can be used in various agriculture sectors either as their original synthetic compounds or their derivatives; after modification, intercalation, etc., $[5,6,8,12,40]$.

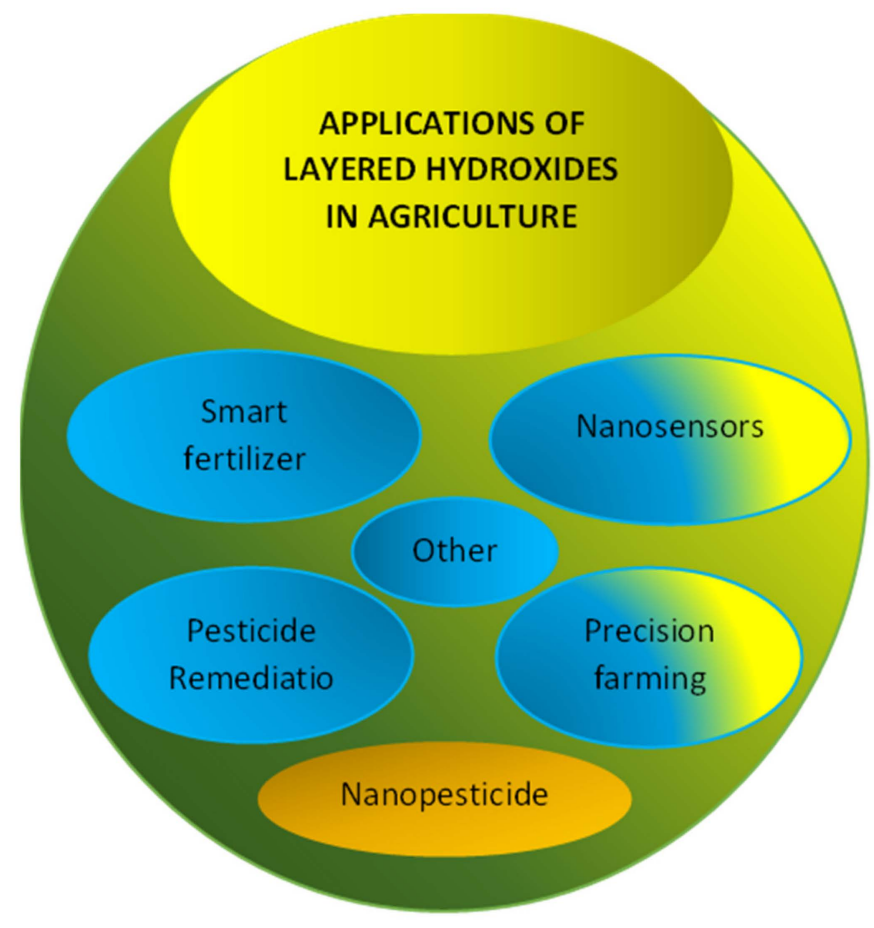

Figure 3. Various applications of layered hydroxides in agriculture.

One of the important applications of LHs and LDHs is the formation of a new generation of pesticides. Various types of pesticides; herbicides, insecticides, fungicides, etc., as the AIs can be intercalated into the LHs and LDHs hosts. The number of combinations of host-guest complexes that can be formed via supramolecular chemistry is huge, thus opening up unlimited opportunities to produce and explore this area of research, development and innovation.

\subsection{Supramolecular Host-Guest Chemistry}

Supramolecular chemistry is the chemistry of molecular assemblies of intermolecular noncovalent bonds that result from the association of two or more chemical entities. The binding of the chemical entities can be from various weak bonds such as hydrogen bonds, Van der Waals, hydrophobic, etc., or even fairly strong bonds such as metal-ligand coordination or electrostatic bonds [41,42].

Host-guest chemistry is the key enabler in constructing various nanomaterials for various applications from agriculture to medicines and from physics to engineering. Currently, supramolecular chemistry is truly interdisciplinary, especially in the nanotechnology era, where research in this area requires various expertise in the areas of biology, biochemistry, chemistry, material science, physics and engineering, etc. Various types of host-guest nanomaterials can be generated using supramolecular chemistry. For example, complex biological structures can be produced by molecular self-assembly, where a spontaneous association of stable molecules via noncovalent bonds results in a well-defined aggregate [43]

One of the important factors for the formation of host-guest supramolecular structures is the interaction between the host and the guest via various processes such as attachment, 
entrapment, encapsulation, intercalation, adsorption, conjugation, or their combinations. This is very much determined by the type of physicochemical properties of the host and the guest and the bond that can be formed between them.

The types of bonds that will be formed between the host and the guest can be from weak bonds such as Van der Waals, hydrogen bonds, hydrophobic forces, etc., or even strong bonds such as metal-ligand coordination or electrostatic bonds.

Nanopesticides can be synthesized using host-guest supramolecular chemistry using LHs or LDHs 2D inorganic layered structure as the host and the AI pesticide as the guest. The formation of the resulting nanopesticide is called a "complex", which refers to the nanopesticides that were formed. The term "intercalation" is usually referred to the encapsulation of the AI into the 2D inorganic layered structure (Figure 4). This can be confirmed by various analytical techniques, and some of the important ones are given in Table 2.

Figure 4 shows a schematic diagram of how layered double hydroxide can be used for the formation of the nanopesticides by adopting host-guest supramolecular chemistry using different approaches; direct co-precipitation, indirect ion exchange and reconstruction, or memory effect methods. Following the formation of the nanopesticides, the release of the guest (the pesticide or the AI) from the host is accomplished either via the ion exchange process, the dissolution of the host or via both. The AI that was released is targeted to the pest. Depending on the surrounding environment, the formation of the "new" LDH with the new incoming anions that are available in the surrounding environment is possible. This can be verified by various analytical techniques, especially the XRD.

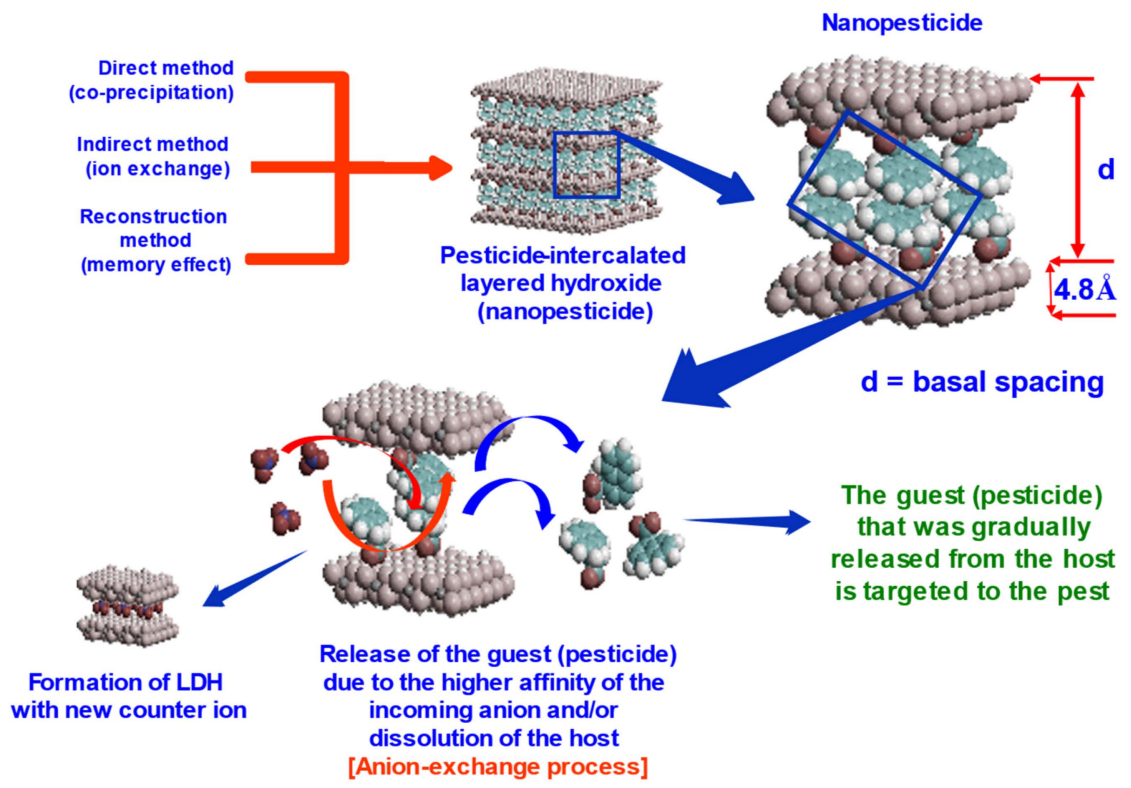

Figure 4. Layered double hydroxide inorganic 2D structure, the formation of the nanopesticides by adopting host-guest supramolecular chemistry, and the release of the guest from the host via the ion exchange process, together with the dissolution of the host and the possible formation of the "new" $\mathrm{LDH}$ with the new incoming anions that are available in the surrounding environment. 
Table 2. Some important physicochemical characterizations of the nanopesticides synthesized by host-guest supramolecular chemistry.

\begin{tabular}{|c|c|}
\hline Techniques & Information on The Physicochemical Properties Obtained \\
\hline Powder X-Ray Diffraction (PXRD) & $\begin{array}{l}\text { Crystallinity, basal spacing, the intercalation of the host into the } \\
\text { guest, the plausible spatial orientation of the guest in the } \\
\text { interlamellar of the host }\end{array}$ \\
\hline $\begin{array}{l}\text { UV-Visible Spectroscopy (UV-vis)/High-Performance Liquid } \\
\text { Chromatography (HPLC) }\end{array}$ & $\begin{array}{l}\text { Pesticide loading and loading efficiency of the guest, kinetic } \\
\text { release of the pesticide from the nanopesticides }\end{array}$ \\
\hline Thermal Analysis (TGA/DTG) & Thermal degradation behavior of the nanopesticides \\
\hline Fourier-Transform Infrared Spectroscopy (FTIR) & $\begin{array}{l}\text { Chemical bonds or functional groups formed between the host } \\
\text { and the guest }\end{array}$ \\
\hline Surface Area Analyzer & Surface area and pore-size distribution of porous nanopesticides \\
\hline Dynamic Light Scattering (DLS) & Particles' size and the distribution of the nanopesticides \\
\hline Field-Emission Scanning Electron Microscope (FESEM) & Surface morphology of the nanopesticides and their distribution \\
\hline High-Resolution Transmission Electron Microscope (HRTEM) & $\begin{array}{l}\text { The internal structure of the nanopesticides and their } \\
\text { distribution }\end{array}$ \\
\hline Direct Injection Mass Spectroscopy (DIMS) & $\begin{array}{l}\text { To confirm the presence of the guest in the interlamellar of the } \\
\text { LH or the LDH hosts. }\end{array}$ \\
\hline Others & $\begin{array}{l}\text { Techniques such as X-Ray Photoelectron Spectroscopy (XPS), } \\
\text { Selected Area Electron Diffraction (SAED), Raman Spectroscopy, } \\
\text { Atomic Force Microscopy, (AFM), Small-Angle X-Ray and } \\
\text { Neutron Scattering Spectroscopy (SAXS/SANS), etc., are also } \\
\text { used to support that the guest is intercalated into the host for } \\
\text { the formation of host-guest nanomaterial. }\end{array}$ \\
\hline
\end{tabular}

\subsection{Method of Synthesis}

There are three main methods that can be adopted to synthesize nanopesticides using host-guest supramolecular chemistry, namely direct, indirect and reconstruction or "memory effect". The direct method involves the co-precipitation of the anions and cations in a controlled $\mathrm{pH}$ environment. In the indirect method, the counter anion that already exists in the interlayers of the $\mathrm{LDH}$ is exchanged with the $\mathrm{AI}$ as the guest from the solution. This can be achieved by placing the preprepared LDH into a solution containing the anion of the pesticide AI so that the anion exchange process will take place, resulting in the intercalation of the new guest, which is the AI for the formation of the host-guest nanomaterial [44-48].

The host-guest supramolecular complex can be also synthesized using the regeneration or the "memory effect". For example, LDH was prepared first and then calcined at a certain temperature to produce a mixed oxides phase. Rehydration by contacting the calcined LDH with an aqueous solution containing anions to be intercalated results in the intercalation of the anion into the LDH lamellar, and this process is called "memory effect". Other methods such as sol-gel, solid hammer mill, micelles-assisted, etc., can be also adopted and the details of these processes can be found elsewhere [49].

\subsection{Physicochemical Characterizations}

In order to confirm whether the host-guest supramolecular complex was formed after the synthesis of the nanopesticides, various physicochemical analyses have to be performed and are only discussed briefly here. Table 2 summarizes the techniques used and the information that can be gathered from them.

The XRD is an excellent technique to confirm the intercalation episode of the guest (pesticide active agent) into the inorganic host (LHs or LDHs). Of course, other supporting techniques are also important to support it. For example, work on the synthesis of nanofungicide using hexaconazole as the $\mathrm{AI}$ into the $\mathrm{Zn} / \mathrm{Al}-\mathrm{LDH}$ interlamellar, resulted 
in the expansion of the basal spacing from 8.72 to $28.87 \AA$, due to the size and spatial orientation of the guest, with hexaconazole compared to nitrate species in the LDH. In addition, four harmonic reflections can be also observed. A slow scan revealed that eight harmonics reflections can be resolved, resulting in a better basal spacing of $29.42 \AA$, an average from the eight harmonics [9].

Using the software, the three-dimensional structure of the guest molecule, hexaconazole, can be obtained. It is known that the $\mathrm{Zn} / \mathrm{Al}$-LDH brucite thickness is $4.8 \AA$, therefore the space available for the spatial orientation of the organic moiety, hexaconazole, is $24.62 \AA$. Therefore, the plausible spatial orientation, taking into account the co-presence of sodium dodecylbenzene sulfonate, is as given in Figure 5 [9].
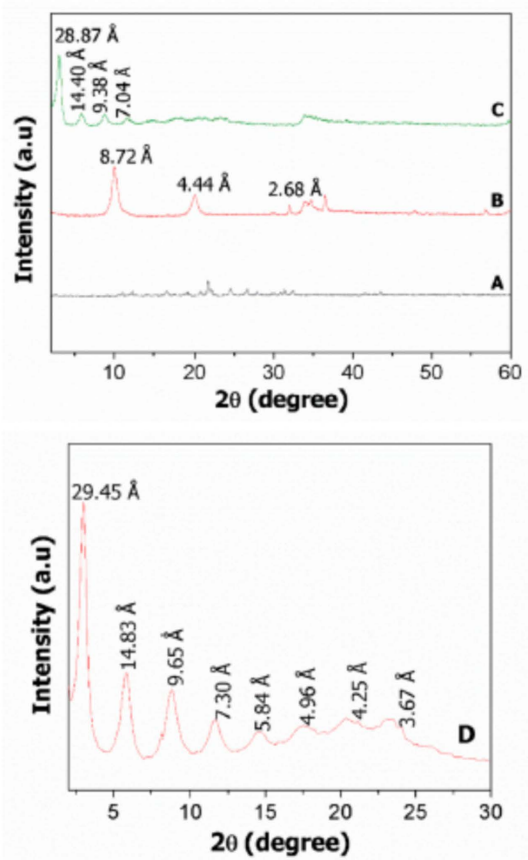

A

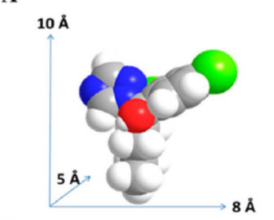

B

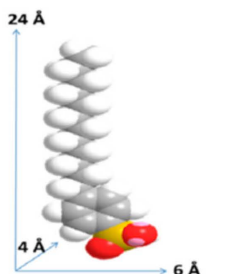

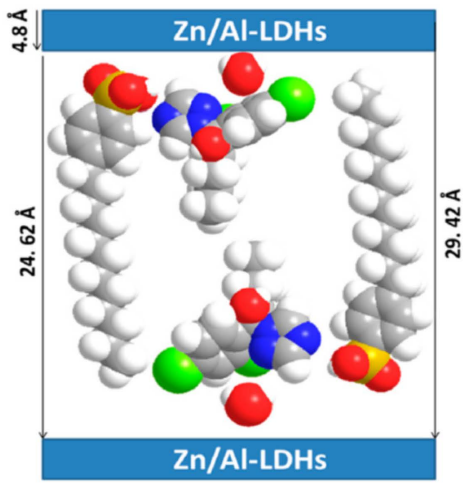

Carbon Nitrogen Sulphur Chlorine $\bigcirc$ Hydrogen $\bigcirc$ Oxygen

Figure 5. XRD patterns of free hexaconazole (A), Zn/Al-LDH (B), and hexaconazole-intercalated Zn/ Al-LDH (the nanofungicide) (C), and the slow scan with a dwell time of $0.5^{\circ} / \mathrm{min}(\mathrm{D})$ showing details of the eight harmonics, and from them the average value of the interlamellar (nxd) was calculated to be $29.42 \AA$ (left figure) and the 3D structure of hexaconazole (A), sodium dodecylbenzenesulfonate (B) and plausible arrangement of hexaconazole and sodium dodecylbenzenesulfonate in the intergalleries of HZALDH nanocomposite (C) (right figure) [9].

\subsection{Controlled-Release Properties}

One of the most important properties of the host-guest supramolecule based on the 2D inorganic layered structure is its ability to release the guest gradually if there exists an external force in the surrounding environment. For example, in the ion exchange process, due to the higher affinity of the incoming anion, the AI that was intercalated will be replaced by it, resulting in the AI being released as the outgoing anion (Figure 4).

For the in vitro study, the nanopesticide is exposed to a buffer solution of certain $\mathrm{pH}$ and the amount of the guest released is measured at a preset time, using analytical techniques such as high-performance liquid chromatography (HPLC) or UV-visible spectroscopy. A plot of cumulative release against time can be obtained. The linear fit of the amount of the released guest is then fitted to mathematical models, where the $\mathrm{R}^{2}$ value together with the plot will help in the selection of the best mathematical model that fits the kinetic release of the guest, the AI.

\subsection{Kinetic Release of the Guest from the Nanopesticides}

Pesticide release is a process where AI leaves the host and eventually becoming available for the biological action. This study involves AI release rate, dissolution, diffusion, 
erosion and the study of the factors that affect the release rate. In vitro releases of AI into a solution under a certain condition are usually used to study the release of the AI from the synthesized nanopesticides [50].

There are many mathematical models to be used that fit the release of the AI from the host into the solution. Buffer solutions of certain $\mathrm{pH}$ are usually used to mimic the physiological environment of the target usage. Among the models used are Fick's First law, Fick's second law, zeroth-order, first-order, second-order, Hixson-Crowell, KorsmeyerPeppas, Wiebull, Higuchi, the Baker-Lonsdale model, the Hopfenberg model, etc. [51-58]. This is summarized in Table 3.

Table 3. A few mathematical models and equations which are often used for controlled-release and kinetic-release characteristics of the AI from the host into the solution.

\begin{tabular}{|c|c|c|c|c|}
\hline No & $\begin{array}{l}\text { Mathematical } \\
\text { Model }\end{array}$ & Equations & Denotations & Source(s) \\
\hline 1 & Zeroth-order & $\mathrm{C}=\mathrm{C}_{0}-\mathrm{K}_{0} \mathrm{t}$ & $\begin{array}{c}\mathrm{C}=\text { Amount of drug released } \\
\mathrm{C}_{0}=\text { Initial amount of drug in solution } \\
\mathrm{K}_{0}=\text { Zeroth-order rate constant } \\
\mathrm{t}=\text { Time }\end{array}$ & [55] \\
\hline 2 & First-order & $\mathrm{dC} / \mathrm{dt}=-\mathrm{KC}$ & $\mathrm{K}=$ First order rate constant & [55] \\
\hline 3 & Second-order & $1-\left(\mathrm{M}_{\mathrm{t}} / \mathrm{M}_{0}\right) / \mathrm{t}=\mathrm{kt}^{-1 / 2}+\mathrm{b}$ & & [58] \\
\hline 4 & Hixson-Crowell & $\mathrm{C}_{0}{ }^{1 / 3}-\mathrm{C}_{\mathrm{t}}^{1 / 3}=\mathrm{Kt}$ & $\begin{array}{c}\mathrm{C}_{\mathrm{t}}=\text { Amount of drug released in time, } \mathrm{t} \\
\mathrm{C}_{0}=\text { Initial amount of drug in table } \\
\mathrm{K}=\text { Rate constant }\end{array}$ & {$[51,55]$} \\
\hline 5 & Fick's first law & $J=-D_{f} d c / d x$ & $\begin{array}{c}\mathrm{J}=\text { Amount of substance passing } \\
\text { perpendicularly through a unit of surface } \\
\text { area per unit of time } \\
\mathrm{D}_{\mathrm{f}}=\text { Diffusion coefficient } \\
\mathrm{dc} / \mathrm{dx}=\text { Concentration gradient }\end{array}$ & [56] \\
\hline 6 & Fick's second law & $\frac{\partial \varphi}{\partial t}=\mathrm{D} \frac{\partial 2 \varphi}{\partial \times 2}$ & $\begin{array}{c}\varphi=\text { Concentration in } \mathrm{mol} / \mathrm{m}^{3} \\
\varphi=\varphi(x, t) \text { is a function that depends on } \\
\text { location } x \text { and time } t \\
D=\text { Diffusion coefficient in } \mathrm{m}^{2} / \mathrm{s}\end{array}$ & [56] \\
\hline 7 & Korsmeyer-Peppas & $\mathrm{F}=\left(\mathrm{M}_{\mathrm{t}} / \mathrm{M}\right)=\mathrm{K}_{\mathrm{m}} \mathrm{t}^{\mathrm{n}}$ & $\begin{array}{c}\mathrm{F}=\text { Fraction of drug release time } \\
\mathrm{M}_{\mathrm{t}}=\text { Amount of drug release time } \\
\mathrm{M}=\text { Total amount of drug dosage } \\
\mathrm{K}_{\mathrm{m}}=\text { Kinetic constant } \\
\mathrm{n}=\text { Diffusion or release exponent } \\
\mathrm{t}=\text { Time }\end{array}$ & [55] \\
\hline 8 & Wiebull & $\begin{array}{l}f(x, \lambda, k)= \\
\left\{\begin{array}{lr}\frac{k}{\lambda}\left(\frac{x}{\lambda}\right)^{k-1} e^{-\left(\frac{x}{\lambda}\right) k} & x \geq 0 \\
0 & x<0\end{array}\right.\end{array}$ & $\begin{array}{c}\mathrm{K}<1=\text { Failure rate decreases over time } \\
\mathrm{K}=1=\text { Failure rate is constant over time } \\
\mathrm{k}>1=\text { Failure rate increases over time }\end{array}$ & [57] \\
\hline 9 & Higuchi & $\mathrm{Q}=\mathrm{K}_{\mathrm{H}} \mathrm{t}^{1 / 2}$ & $\begin{array}{c}\mathrm{Q}=\text { Cumulative amount of drug released at } \\
\text { the time, } \mathrm{t} \\
\mathrm{K}_{\mathrm{H}}=\text { Higuchi constant } \\
\mathrm{t}=\text { Time }\end{array}$ & [52] \\
\hline 10 & Baker-Lonsdale & $\begin{array}{c}\mathrm{F}_{1}=3 / 2\left(1-\left(1-\mathrm{C}_{\mathrm{t}} / \mathrm{C}_{\infty}\right)^{2 / 3)}\right. \\
\mathrm{C}_{\mathrm{t}} / \mathrm{C}_{\infty}=\mathrm{kt}\end{array}$ & $\begin{array}{c}\mathrm{C}_{\mathrm{t}}=\text { Drug release amount at time, } \mathrm{t} \\
\mathrm{C}_{\infty}=\text { Amount of drug released } \\
\mathrm{K}=\text { Release constant }\end{array}$ & {$[53,55]$} \\
\hline 11 & Hopfenberg & $\mathrm{Q}_{\mathrm{t}} / \mathrm{Q}_{\infty}=1-\left(\mathrm{K}_{0 \mathrm{t}} / \mathrm{C}_{0 \mathrm{a} 0}\right)$ & $\begin{array}{c}\mathrm{Q}_{\mathrm{t}}=\text { Amount of drug released in time, } \mathrm{t} \\
\mathrm{Q}_{\infty}=\text { Amount of drug dissolved when the } \\
\text { dosage form is exhausted } \\
\mathrm{C}_{0}=\text { Initial concentration of the drug } \\
\mathrm{A}_{0}=\text { Initial radius sphere for a slab }\end{array}$ & [54] \\
\hline
\end{tabular}

By looking at the mathematical models, from the best-fitted model of the release of the AI from the host we can deduce the mechanism of the release. For example, if the release of the $\mathrm{AI}$ is governed by the Hixson-Crowell Equation, then the mechanism for drug release is by dissolution, involving changes in surface area and diameter of the nanoparticles, and so the release mechanism is not by diffusion. The details of these mathematical models can be found elsewhere $[51-54,59,60]$. 


\section{Nanopesticides Synthesized Using 2D Inorganic Layered Hydroxides Hosts}

For the 2D inorganic layered hosts, most of the RDIs are focusing on the layered hydroxides. Therefore, our review is based only on three types of hosts, namely zinclayered hydroxide, magnesium/aluminum-layered double hydroxide and zinc/aluminumlayered double hydroxide, together with other LDHs.

\subsection{Zinc Layered Hydroxide}

LH has a 2D inorganic layered structure, which is composed of a single metal hydroxide. $\mathrm{Zn}$ - $\mathrm{LH}$ is the most common one used to host various AI guests for the synthesis of nanopesticides that can be found in the literature, as shown in Table 4. For example, isoprocarb and carbamate were separately intercalated into the $\mathrm{Zn}-\mathrm{LH}$ for the formation of their nanoinsecticides, resulting in better thermal stability and environmental friendliness of the AI compared with their counterparts [61,62].

Table 4. Nanopesticides synthesized using host-guest supramolecular chemistry using zinc-layered hydroxide as the host and various AIs as the guest for various targets and advantages.

\begin{tabular}{|c|c|c|}
\hline AI Guests & Target/Advantages & Source(s) \\
\hline Isoprocarb & $\begin{array}{l}\text { A mesoporous-type material forming an } \\
\text { environmentally friendly insecticide }\end{array}$ & {$[61]$} \\
\hline Carbamate & $\begin{array}{l}\text { A significantly improved thermal stability } \\
\text { of the anion compared to its pure form. }\end{array}$ & {$[62]$} \\
\hline 3-(4-Methoxyphenyl) Propionic & $\begin{array}{l}\text { Can be synthesized using ion exchange } \\
\text { and co-precipitation methods for the } \\
\text { formation of a new generation } \\
\text { of agrochemicals. }\end{array}$ & {$[63]$} \\
\hline Imidacloprid & $\begin{array}{l}\text { Good controlled-release properties, } \\
\text { overcoming the excessive usage of } \\
\text { insecticide in paddy cultivation. }\end{array}$ & {$[64]$} \\
\hline $\begin{array}{l}\text { 4-(2,4-Dichlorophenoxy) Butyrate and } \\
\text { 2-(3-Chlorophenoxy) Propionate }\end{array}$ & $\begin{array}{l}\text { Has the dual-guest controlled-release } \\
\text { formulation }\end{array}$ & {$[65]$} \\
\hline 2-Methyl-4-Chlorophenoxyacetic & $\begin{array}{l}\text { Has sustained release of the AI from } \\
\text { the nanopesticides. }\end{array}$ & {$[66]$} \\
\hline 3-glycidyloxypropyl) Trimethoxysilane & $\begin{array}{l}\text { The release of the AI was governed by the } \\
\text { pseudo-second-order and } \\
\text { parabolic-diffusion Models. }\end{array}$ & {$[67]$} \\
\hline Sodium Dodecyl Sulfate & $\begin{array}{l}\text { Improvement of an environmentally } \\
\text { friendly pesticide formulation }\end{array}$ & [68] \\
\hline Chlorpyrifos/Dodecylbenzenesulfonate & $\begin{array}{l}\text { The intercalated pesticide has higher } \\
\text { thermal stability. The release rates and } \\
\text { equilibrium release amounts of the } \\
\text { pesticide were closely dependent on } \\
\text { micelles types and release media }\end{array}$ & {$[69]$} \\
\hline
\end{tabular}

Other pesticides that were intercalated into $\mathrm{Zn}-\mathrm{LH}$ are 3-(4-methoxyphenyl) propionic [63], imidacloprid [64], 4-(2,4-dichlorophenoxy) butyrate and 2-(3-chlorophenoxy) propionate [65] and 2-methyl-4- chlorophenoxyacetic [66]. They were synthesized due to their superior qualities compared with their counterparts.

A pesticide, 3-glycidyloxypropyl trimethoxysilane was intercalated into the $\mathrm{Zn}-\mathrm{LH}$ host for the formation of its nanopesticides. The release of the AI was found to be governed by the pseudo-second-order and parabolic-diffusion models [67]. Sodium dodecyl sulfate [68] and chlorpyrifos [69] also were intercalated separately into the LH host either directly (for the former) or indirectly using a surfactant such as dodecylbenzenesulfonate in the latter. Both of them were claimed to be more superior compared to their counterparts.

As shown in the table, advantages such as being environmentally friendly, improved thermal stability and controlled-release properties are the superior qualities obtained when the host-guest complex nanopesticides were formed from their AI counterparts. This is why these type of nanopesticides are worth exploring as they provide many benefits. 


\subsection{Zinc/Aluminum-Layered Double Hydroxide}

$\mathrm{Zn} / \mathrm{Al}-\mathrm{LDH}$ is subjected to more intense research compared to other LDHs, regarding its use as the host of various AI pesticides for various nanopesticide applications. This is because it is relatively simple and cheap to prepare, and it is easier to form the $2 \mathrm{D}$, well-ordered, inorganic, layered structure with good crystallinity.

Table 5 shows the nanopesticides prepared using host-guest supramolecular chemistry based on $\mathrm{Zn} / \mathrm{Al}-\mathrm{LDH}$. AIs such as mandelic acid were intercalated into $\mathrm{Zn} / \mathrm{Al}-\mathrm{LDH}$ to be used as slow-release preservatives and for crop protection [70]. Herbicides or defoliants; 2,4-dichlorophenoxy and 4-chlorophenoxy acetate were simultaneously intercalated into the $\mathrm{Zn} / \mathrm{Al}-\mathrm{LDH}$ and were found to be promising candidates which can simultaneously control the release of the two AIs at differently controlled rates [71]. Similarly, 2,4-dichlorophenoxyacetic acids in the presence of glyphosate showed better herbicide properties [72].

Table 5. Nanopesticides prepared using host-guest supramolecular chemistry based on a Zn/Al-LDH host using various guests, AIs, for various targets and advantages.

\begin{tabular}{|c|c|c|}
\hline AI Guest & Target/Advantages & Source(s) \\
\hline Dazomet & $\begin{array}{l}\text { The nanodelivery system also shows better inhibition towards } \\
\text { Ganoderma boninense growth, to be further explored for } \\
\text { combating basal stem rot (BSR) disease in oil palm plantations. }\end{array}$ & [73] \\
\hline Quinclorac & $\begin{array}{l}\text { To overcome the drawbacks of the overuse of herbicides in } \\
\text { paddy cultivation areas }\end{array}$ & {$[64]$} \\
\hline Mandelic Acid & $\begin{array}{l}\text { To be used as a slow-release preservative, and additionally for } \\
\text { crop protection }\end{array}$ & [70] \\
\hline $\begin{array}{l}\text { 2,4-Dichlorophenoxy Acetate and } \\
\text { 4-Chlorophenoxy Acetate }\end{array}$ & $\begin{array}{l}\text { As a plant growth regulator, controlled release of more than one } \\
\text { AI at different controlled rates }\end{array}$ & {$[71]$} \\
\hline $\begin{array}{l}\text { 2,4-Dichlorophenoxyacetic Acids @ } \\
\text { Glyphosate }\end{array}$ & $\begin{array}{l}\text { Has slow-release properties in decarbonated distilled water, the } \\
\text { potential applicability of LDHs as supports for the slow release } \\
\text { of acid herbicides }\end{array}$ & {$[72]$} \\
\hline Quinclorac & Better thermal stability compared to pure herbicide. & [74] \\
\hline Carbonate Anion & Can be used as an antimicrobial agent & [73] \\
\hline Hexazonazole & $\begin{array}{l}\text { Dual-modal fungicide nanodelivery system, as a fungicide } \\
\text { delivery Agent and a micronutrient supplier, to support early } \\
\text { plant growth and has the potential to avoid direct contact of } \\
\text { fungicides with users due to the intercalation process. }\end{array}$ & [75] \\
\hline Nalidixic Acid & $\begin{array}{l}\text { Increases the effectiveness for pest control and minimizes } \\
\text { possible soil and water contamination }\end{array}$ & [76] \\
\hline Nalidixic Acid & Can be used to control pests, infestation and plant disease. & [77] \\
\hline Pipemidic and Nalidixic Acid & $\begin{array}{l}\text { Organic biocides can eliminate almost completely bacteria } \\
\text { within a short time }\end{array}$ & [78] \\
\hline $\begin{array}{l}\text { 2-(2,4-Dichlorophenoxy) Acetic Acid, } \\
\text { 2-Methyl-4-Chlorophenoxyacetic Acid } \\
\text { (MCPA) and } \\
\text { 3,5-Dibromo-4-Hydroxybenzonitrile }\end{array}$ & $\begin{array}{l}\text { The } \mathrm{Zn} / \mathrm{Al} \text {-LDH nanoherbicides were prepared by a modified } \\
\text { co-precipitation method. The nanoherbicides formed were } \\
\text { found to reduce the volatilization by } 3 \text {-fold and retard leaching } \\
\text { through the soil, simultaneously }\end{array}$ & [79] \\
\hline Avermectin & $\begin{array}{l}\text { Well-control the release of avermectin, a promising candidate } \\
\text { for water-dispersible controlled-release formulation }\end{array}$ & [80] \\
\hline Bacteriocin Avicin & $\begin{array}{l}\text { Potent antimicrobial activity against Lactobacillus in a short } \\
\text { period }(24 \mathrm{~h}) \text {, better production and stability }\end{array}$ & [81] \\
\hline Benzoate and its Derivatives & $\begin{array}{l}\text { Having a diverse rate of killing depending on the derivatives, } \\
\text { the active was released very slowly }\end{array}$ & {$[82]$} \\
\hline Carboxymethyl Cellulose & $\begin{array}{l}\text { Offers the solution for the downside effect of the excessive } \\
\text { usage of herbicide in paddy cultivation }\end{array}$ & [83] \\
\hline Chitosan & Enhanced antimicrobial effect & [84] \\
\hline Chlorpyrifos/cyclodextrin & $\begin{array}{l}\text { The nanopesticides showed distinct slow release due to the } \\
\text { different arrangements of cyclodextrin, the release rate of the AI } \\
\text { from nanohybrids was faster and the amount released was } \\
\text { higher at } \mathrm{pH} 6.8 \text { than at } \mathrm{pH} 5.0\end{array}$ & [85] \\
\hline
\end{tabular}


Table 5. Cont

\begin{tabular}{clll}
\hline AI Guest & \multicolumn{1}{c}{ Target/Advantages } & Source(s) \\
\hline $\begin{array}{c}\text { Pectin/cinnamate acid } \\
\text { Cinnamate anion }\end{array}$ & $\begin{array}{l}\text { Dual applications; cosmetics and crop protection } \\
\text { Green protective coatings for crops' protection. }\end{array}$ & [86] \\
$\begin{array}{c}\text { Ciprofloxacin, sulfanilamide, and } \\
\text { oxazolidinone }\end{array}$ & $\begin{array}{l}\text { Offer a promising antimicrobial nanomaterial for various } \\
\text { applications }\end{array}$ & [88] \\
$\begin{array}{c}\beta-\text { Cypermethrin in sulfonated } \\
\text { hydroxyethyl- } \beta \text {-cyclodextrin and sulfobutyl } \\
\text { ether } \beta \text {-cyclodextrin }\end{array}$ & $\begin{array}{l}\text { The released amount of AI can be tuned by the pH. Can be used } \\
\text { for nanopesticide controlled-release formulation }\end{array}$ \\
Eucalyptus oil & $\begin{array}{l}\text { Very effective at very low concentrations, able to kill } \\
\text { Staphylococcus sp. and inhibit Pseudomonas aeruginosa growth }\end{array}$ \\
\hline
\end{tabular}

Quinclorac-intercalated LDH is more stable than its free AI form, and can be used as a nanopesticide for rice crop protection [64,74]. Carbonate was used as the guest, and the nanopesticide formed was found to be a better alternative for an antimicrobial agent than its counterpart [73].

The fungicides hexaconazole and dazoment were intercalated separately into the $\mathrm{Zn} / \mathrm{Al}-\mathrm{LDH}$, and the resulting nanofungicides were found to be more potent than their AIs in treating basal stem rot disease of oil palm trees, one of the important economical crops of palm oil producers such as Malaysia, Indonesia, etc. In addition, the presence of Zn from the inorganic layer helps the early stage growth of the young oil palm [75]. Their superior quality is believed to be due to the controlled-release property, resulting in better bioavailability and less toxicity, due to the deintercalation of the AIs into the LDH interlayers by the ion-exchange process.

$\mathrm{Zn} / \mathrm{Al}-\mathrm{LDH}$-nalidixic acid nanopesticide is used to control pest infestation and plant diseases [76], increasing the effectiveness of pest control and minimizing possible soil and water contamination [77]. This organic biocide was found to be very effective, which can eliminate almost completely bacteria within a short time. Similar properties were also observed for pipemidic acid-intercalated Zn/Al-LDH [78]. Furthermore, 4-(2,4Dichlorophenoxy) butyrate nanohybrid [90] and 4-chlorophenoxyacetic acid [91] were also used as the guests for the synthesize of nanopesticides. In the former, the organic moiety can be more easily released and the release property of the guest can be tuned up. In the latter, it provides an alternative for low-cost and green herbicides.

Defoliants are chemicals that are adsorbed by broad-leafed plants and kill them due to excessive hormonal growth. Organic active agents such as 2,4-dichlorophenoxyacetic acid and 2,4,5-trichlorophenoxyacetic acid, tribufos, dimethipin, and thidiazuron are examples of chemicals that are used as defoliants. These compounds are used to selectively kill weeds and unwanted plants. They are also helpful for effective harvesting of certain crops, such as cotton, etc. Research on nanodefoliants with controlled-release properties was achieved by the intercalation of the herbicides 2-(2,4-dichlorophenoxy) acetic acid, 2-methyl-4-chlorophenoxyacetic acid (MCPA) and 3,5-dibromo-4-hydroxybenzonitrile (bromoxynil) into the $\mathrm{Zn} / \mathrm{Al}-\mathrm{LDH}$ nanosheets by a modified co-precipitation method. The nanodefoliants formed were found to reduce the volatilization by 3 -fold and retard leaching through the soil, simultaneously [79].

Avermectin is used in agriculture and horticulture to control insect pests on many crops and ornamentals. Its intercalated product using the $\mathrm{Zn} / \mathrm{Al}-\mathrm{LDH}$ as the host shows better water-dispersible controlled-release formulation [80]. Potent antimicrobial activity against Lactobacillus in a short period, better production and better stability were obtained using Bacteriocin avicin [81]. Benzoate and its derivatives were also subjected to an intercalation process, where the AI was released very slowly, resulting in the rate of killing being depending on the derivatives used [82].

Carboxymethyl cellulose-intercalated Zn/Al-LDH nanopesticide offers a better agronanochemical to reduce the excessive usage of herbicide in paddy cultivation [83], while its chitosan counterpart could enhance the antimicrobial effect compared to its AI [84]. Similar 
work on chlorpyrifos/cyclodextrin indicated the slow-release property, which is due to the different arrangements of cyclodextrin in the resulting synthesized material. In addition, the release rate of the $\mathrm{AI}$ from nanohybrids was $\mathrm{pH}$-dependent [85].

Cinnamate anion-intercalated Zn/ Al-LDH gives green protective coatings for crops' protection $[86,87,92]$. Intercalated ciprofloxacin, sulfanilamide, and oxazolidinone, and the nanopesticide products were found to improve the antimicrobial properties of the AIs.

The intercalation of $\beta$-cypermethrin in sulfonated hydroxyethyl- $\beta$-cyclodextrin and sulfobutyl ether $\beta$-cyclodextrin resulted in nanopesticides, in which the release rate of the AIs can be tuned using the $\mathrm{pH}$ [88]. The work on the intercalation of a natural product such as Eucalyptus oil is very promising, where the amount of the effective AI can be reduced to very low concentrations, able to kill Staphylococcus sp. and inhibit Pseudomonas aeruginosa growth [89]. Last but not least, pectin/cinnamate acid-intercalated Zn/Al-LDH resulted in dual applications; cosmetics and crop protections [86].

As shown in the above table, the advantages of the superior qualities when the host, $\mathrm{Zn} / \mathrm{Al}-\mathrm{LDH}$, was used to guest the AIs for the formation of the nanopesticides are similar to the zinc layered hydroxide (ZLH) host, but the latter is much easier and cheaper to prepare because only one metal cation, $\mathrm{Zn}^{2+}$ is used for the formation of the inorganic, 2D layered structure. In addition, based on the previous studies, the presence of the $\mathrm{Zn}^{2+}$ could help the growth of the seedling [9,75]. Therefore, the Zn/Al-LDH not only acts as the host but also serves to supply micronutrients to the crops.

\subsection{Magnesium/Aluminum-Layered Double Hydroxide}

Magnesium/aluminum-layered double hydroxide $(\mathrm{Mg} / \mathrm{Al}-\mathrm{LDH})$ is in the family of LDHs where the inorganic 2D layered structure is composed of $\mathrm{Mg}^{2+}$ and $\mathrm{Al}^{3+}$ cations and this inorganic sheet is positively charged. The counter anions are inserted into the intergallery of the $\mathrm{Mg} / \mathrm{Al} 2 \mathrm{D}$ inorganic structure to balance the charge so that the resulting materials are neutrally charged.

Many AIs can be used as the counter anions as shown in Table 6 . The choice is very much dependent on the final target use and the different desired advantages of the properties of the nanomaterial, LDH, such as controlled properties, higher thermal stability, etc. Herbicides such as (4-chloro-2-methylphenoxy) acetic acid [93], 2,4-dichlorophenoxyacetic acid [94], 2-methyl-4-chlorophenoxyacetic acid [95] and atrazine [96] were used for the intercalation process so that the resulting nanoherbicides formed have slow-release properties, which then reduce the environmental hazards. Other special properties of these nanoherbicides are given in Table 6.

Table 6. Nanopesticides prepared using host-guest supramolecular chemistry based on a Mg/Al-LDH host using various guests, AIs, for various targets and advantages.

\begin{tabular}{|c|c|c|}
\hline AI Guests & Target/Advantages & Source(s) \\
\hline Atrazine & $\begin{array}{l}\text { The herbicide would be delivered close to its site of uptake, } \\
\text { enhancing efficiency and reducing the required dose }\end{array}$ & [96] \\
\hline 4-Chloro-2-Methylphenoxy Acetic Acid & $\begin{array}{l}\text { Slow release of the herbicide reduces the hazardous effects } \\
\text { that it can pose to the environment. }\end{array}$ & [93] \\
\hline 2,4-Dichlorophenoxyacetic Acid & $\begin{array}{l}\text { A stronger and irreversible herbicidal effect on the } \\
\text { test plants }\end{array}$ & [94] \\
\hline 2-Methyl-4-Chlorophenoxyacetic Acid & $\begin{array}{l}\text { Higher loading of the AI herbicide and exhibits better } \\
\text { adsorption properties }\end{array}$ & [95] \\
\hline Camphorsulfonic Acid and Ciprofloxacin & Remarkable improvement in thermal stability & [97] \\
\hline Cinnamic Acid & A green pesticide/plant growth regulator & [98] \\
\hline Hexaconazole and Triadimenol & $\begin{array}{l}\text { Loading amount of hexaconazole is higher than triadimenol } \\
\text { in the LDHs nanohybrids }\end{array}$ & [99] \\
\hline Imazamox & $\begin{array}{l}\text { Decreasing water-pollution risk, maintaining efficacy with } \\
\text { the advantages of soil compatibility. }\end{array}$ & [100] \\
\hline
\end{tabular}


Table 6. Cont.

\begin{tabular}{clc}
\hline AI Guests & \multicolumn{1}{c}{ Target/Advantages } & Source(s) \\
\hline $\begin{array}{c}\text { Long-Chain (C-18) Unsaturated Fatty Acid } \\
\text { Anions; Elaidate, Oleate, and Linoleate }\end{array}$ & $\begin{array}{l}\text { Reduced affinity of the organo-LDHs to all pesticides, } \\
\text { presumably because they lead to structures with reduced } \\
\text { hydrophobicity compared to those resulting from the } \\
\text { incorporation of linear organic anions. }\end{array}$ \\
\hline Sulfamerazine and Salicylaldehyde & Offer good antimicrobial activity & [101] \\
\hline
\end{tabular}

Ciprofloxacin is fluoroquinolone antibiotic, broad-spectrum antimicrobial and is an important class of drugs for both human and animal health [103]. Its nanopesticide complex with $\mathrm{Mg} / \mathrm{Al}-\mathrm{LDH}$ gave higher thermal stability and other CRF properties, resulting in its superior quality compared with its counterpart [97].

Cinnamic acid is a plant growth regulator (PGR) in the cis form [104] but it is an anti-auxin in its trans form $[98,105]$. Both of them were separately intercalated into the $\mathrm{Mg} / \mathrm{Al}-\mathrm{LDH}$ and the resulting nanopesticide can be used as a green pesticide based on its required effect.

Hexaconazole and triadimenol are fungicides used to control various fungal diseases. The former can be used to treat basal stem rot disease in oil palm trees [9] and the latter is used as a fungicide for pineapple pine seedlings, Christmas trees, residential (sod farm) and commercial turf, ornamentals, and landscapes. It is also used as a seed treatment on barley, corn, cotton, oats, rye, sorghum, and wheat [106]. These two AIs were found to form their $\mathrm{Mg} / \mathrm{Al}-\mathrm{LDH}$ complexes where the percentage loading of hexaconazole is higher than triadimenol [99].

Imazamox is an herbicide to prevent plant regrowth and emergent vegetation. Unfortunately, the repeated use of this herbicide with the same mode of action can lead to herbicide-resistant plants [107]. It is generally safe for nontarget species, including humans, but the possibility of toxicity through interfering with other biochemical pathways cannot be ruled out. Intercalation of imazamox will decrease water-pollution risk and maintain efficacy with the advantages of soil compatibility [100].

As shown in Table 4, other AIs useful for plant protection such as camphorsulfonic acid [97], long-chain (C18) unsaturated fatty acid anions; elaidate, oleate, and linoleate [101], sulfamerazine and salicylaldehyde [102] were also subjected to the intercalation into the $\mathrm{Mg} / \mathrm{Al}-\mathrm{LDH}$ nanosheets for the formation of their respective complexes for the obvious reason; the superior physicochemical properties of the host-guest nanomaterials, especially the CRF properties.

Similar to ZLH and Zn/Al-LDH as the hosts, the Mg/Al-LDH host could provide micronutrients, magnesium to promote crop growth, and at the same time acted as the nanopesticide for plant protection, in addition to its superior qualities. These bifunctional properties are important for high throughput agricultural practices.

\subsection{Other Layered Double Hydroxides}

Apart from $\mathrm{Zn} / \mathrm{Al}-\mathrm{LDH}$ and $\mathrm{Mg} / \mathrm{Al}-\mathrm{LDH}$, other layered double hydroxides were also used as the hosts for different AIs such as $\mathrm{Co} / \mathrm{Cr}-, \mathrm{Mg} / \mathrm{Fe}-, \mathrm{Mg} / \mathrm{Al} / \mathrm{Fe}-, \mathrm{Zn} / \mathrm{Cr}-$ and $\mathrm{Zn} / \mathrm{Cu}$-LDH (Table 7). For example, haloxyfop and hexaflumuron were intercalated into the $\mathrm{Co} / \mathrm{Cr}$-LDH for the formation of nanoinsecticides [108]. A herbicide, 4-chloro2-methylphenoxy) acetic acid, was intercalated into $\mathrm{Mg} / \mathrm{Fe}-$ and $\mathrm{Mg} / \mathrm{Al} / \mathrm{Fe}-\mathrm{LDH}$ for the slow release of the herbicide to reduce the hazardous effects that it can pose to the environment [93]. 
Table 7. Nanopesticides prepared using host-guest supramolecular chemistry based on various LDH hosts using various guests, AIs, for various targets and advantages.

\begin{tabular}{|c|c|c|c|}
\hline Hosts & Guests & Target/Advantages & Source(s) \\
\hline $\begin{array}{l}\mathrm{Mg} / \mathrm{Fe}-\mathrm{LDH} \text { and } \\
\mathrm{Mg} / \mathrm{Al} / \mathrm{Fe}-\mathrm{LDH}\end{array}$ & 4-Chloro-2-Methylphenoxyacetic acid & $\begin{array}{l}\text { Slow release of the herbicide } \\
\text { reduces the hazardous effects } \\
\text { that it can pose to the } \\
\text { environment. }\end{array}$ & [93] \\
\hline $\mathrm{Co} / \mathrm{Cr}-\mathrm{LDH}$ & $\begin{array}{l}\text { Haloxyfop (anionic form) and } \\
\text { insecticide (hexaflumuro, neutral form) }\end{array}$ & $\begin{array}{l}\text { A general and reliable } \\
\text { alternative for the analysis of } \\
\text { acidic pesticides in anionic and } \\
\text { neutral forms. }\end{array}$ & [108] \\
\hline $\mathrm{Zn} / \mathrm{Cu}-\mathrm{LDH}$ & $\begin{array}{l}\text { Biocides (zinc pyrithione and copper } \\
\text { pyrithione) }\end{array}$ & $\begin{array}{l}\text { The nanopesticides } \\
\text { demonstrated lower toxicity } \\
\text { compared to their free forms, } \\
\text { good candidates for } \\
\text { antifouling application }\end{array}$ & [109] \\
\hline $\mathrm{Zn} / \mathrm{Cu}-\mathrm{LDH}$ & Isomers of hydroxycinnamate & $\begin{array}{l}\text { The orthoisomer showed a } \\
\text { more sustained release } \\
\text { compared to the other isomers }\end{array}$ & [110] \\
\hline $\mathrm{Li} / \mathrm{Al}-\mathrm{LDH}$ & $\begin{array}{l}\text { 4-Chlorophenoxyacetate, } \\
\text { 2,4-dichlorophenoxyacetic and } \\
\text { 2,4,5-trichlorophenoxyacetate }\end{array}$ & $\begin{array}{l}\text { The intercalation and } \\
\text { deintercalation of the AIs were } \\
\text { found to be dependent on the } \\
\text { type of chlorophenoxyacetic } \\
\text { acid used. }\end{array}$ & [111] \\
\hline
\end{tabular}

$\mathrm{Zn} / \mathrm{Cu}-\mathrm{LDH}$ also was used to host the biocides zinc pyrithione and copper pyrithione for the formation of nanopesticides with lower toxicity compared to their free forms. The nanopesticides were found to be a good candidate for antifouling applications [109]. The same host was also used for the intercalation of hydroxycinnamate where the orthoisomer showed a more sustained release compared to the other isomers [110].

According to Ragavan et al., 2006 [111] 4-chlorophenoxyacetate, 2,4-dichlorophenoxya cetic and 2,4,5-trichlorophenoxyacetate were intercalated into $\left(\mathrm{LiAl}_{2}(\mathrm{OH})_{6}\right) \mathrm{Cl} \cdot x \mathrm{H}_{2} \mathrm{O} \mathrm{LDH}$ $((\mathrm{Li}-\mathrm{Al}-\mathrm{Cl}) \mathrm{LDH})$ by the ion-exchange method. The intercalation and deintercalation of the AIs were found to be dependant on the type of chlorophenoxyacetic acid used.

Algaecides are active agents that kill or prevent the growth of algae. So far, not many works on nanoalgaecides can be found in the open literature. It was indicated that $\mathrm{Zn} / \mathrm{Fe}-$ LDH can be used as a photocatalyst under visible light for Microcystis aeruginosa inhibition, without the requirement of any active agent [40].

The use of various $\mathrm{M}^{2+}$ and $\mathrm{M}^{3+}$ for the formation of the inorganic, 2D, layered structure of the LDHs to host the AIs is beneficial because it promotes crop growth, where the $\mathrm{M}^{2+}$ and $\mathrm{M}^{3+}$ could provide micronutrients after the release of the AIs from the LDH interlayer. Again, the resulting nanopesticides are expected to have bifunctional properties which are important for high yield in modern agriculture.

\section{Practical Applications, Future Research Perspectives, Challenges and Limitation}

Based on the works of literature, it is clear that nanopesticides generally offer superior qualities, which are more potent, more economical, and user and environmentally friendly compared with their conventional counterparts, and therefore have promising practical applications. This is due to the fact that the same agricultural practice can be adopted, but we simply switch the conventional pesticides to nanopesticides. In addition, the synthesis of nanopesticides using the host-guest supramolecular chemistry approach is relatively simple and cost-effective, where the same commercially available AIs can be used as the guests. The cost for transforming conventional pesticides to their nanopesticides counterparts is outweighed by their benefits, and put together with their superior qualities to the human life and the environment, surely nanopesticides have promising practical applications in the agricultural sector.

The current RDIs are focusing more on single guest AI and only a few works have attempted on the simultaneous intercalation of two AIs for bifunctional nanopesticides. Multifunctional nanopesticides are the way forward, in parallel with the demand of the current high-throughput agricultural practices. In addition, multimodal agro-nanochemicals 
where macro- and micro-nutrients can be combined with plant protection agents are also important to achieve holistic, efficient crop management. Although findings within the literature for a product at the laboratory scale seem promising, the commercialization usually has to follow several steps, upscaling, field studies, etc. Upscaling of the production of the nanopesticides is another challenge in terms of reproducibility, quality assurance and cost effectiveness. This is another stage of RDI of new products in which financial support is crucial.

Many of the AIs of pesticides are classified under the regulations for use in their agricultural practices and the regulations are usually different for different countries. Again, RDI is important from seed technology to the nursery, and from field studies to postharvest. For the field studies, residual and efficacy analyses are important, where together with nanotoxicology data they are important to obtain the license of commercialization in terms of production, storage, selling and use for the agriculture sector. For commercialization, intellectual property is important to protect the new product from being copied by other parties. Due to related costs of legal fees, etc., which are quite expansive, sometimes this becomes another limitation against the new nanopesticides becoming available at the commercial scale.

Another challenge of a new product is the general acceptance of the public or the planters to switch from their existing familiar product to a new one. Establishing the product in the market via advertisement, etc., is another challenge that is not part of the scientific work but has to be done.

\section{Way Forward}

In this review, we have discussed the current scenario of the research, development and innovation (RDI) for the up conversion of various currently available active ingredient of pesticides for plant protection through nanotechnology platforms using various 2D, inorganic, nanolayered materials; layered hydroxides and layered double hydroxides. The findings from the literature agreed that the resulting nanopesticides have superior qualities compared to their counterparts, and therefore the efforts towards the generation of new agro-nanochemicals which are superior to their conventional counterparts are worth the effort.

Although the RDIs in these areas were quite extensive, not all the toxicology issues, the toxicology benchmark or standard technical characterization in determining the toxicity of the nanomaterials used for host-guest supramolecular chemistry were cared for. Therefore, the nanotoxicology of the nanopesticides is the next direction we shall focus on.

Due to vast types of pesticide active ingredients available in the market that can be used as the guest for the generation of nanopesticides, generalization on their toxicity cannot be easily made. Therefore, it is undeniable that many negative impacts are still underexplored. This includes the toxicity impact of the AIs, as well as the host, and the resulting nanomaterials when they form nanopesticides. Therefore, RDI should be continued and at the same time work on the strategies of integrating the knowledge and sharing them towards comprehensive databases and standards is required, so that these new generations of agrochemicals can benefit not only the agricultural industries but also the user and the environment.

\section{Conclusions}

This manuscript reviews the use of various 2D, brucite-like inorganic layered structures, namely layered hydroxides and layered double hydroxides, to hosts various types of pesticide active ingredients for the formation of various nanopesticides for plant protection. Among them, zinc layered hydroxides and zinc/aluminium-layered double hydroxide were found to be the most popular choices to be used as the host, presumably due to their relative ease to prepare and cheap cost. Other hosts including $\mathrm{Mg} / \mathrm{Al}-, \mathrm{Co} / \mathrm{Cr}-, \mathrm{Mg} / \mathrm{Fe}-$, $\mathrm{Mg} / \mathrm{Al} / \mathrm{Fe}-, \mathrm{Zn} / \mathrm{Cr}$ - and $\mathrm{Zn} / \mathrm{Cu}-\mathrm{LDH}$ were also used. The type of AIs intercalated as the guests were found to be wide-ranging, from fungicides to herbicides and from defoliants to 
plant growth regulators. As the preparation step is fairly straightforward, this is only a step further, where the same AIs of agrochemicals can be used, and therefore the processing cost can be outweighed by the benefits. These structures are more economical, have better efficacy, and are safer to the life, human beings and the environment. This enables us to move on from conventional agrochemicals to a safer, new generation of agrochemicals, "agro-nanochemicals", produced using nanotechnology platforms. This looks towards the holistic management of pesticides for crop protection using nanotechnology platforms for high-throughput agricultural products.

Author Contributions: Conceptualization, S.A.M.Z., A.A., F.A., M.R.S. and K.A.; methodology, S.A.M.Z.; investigation, S.A.M.Z. and K.A.; data curation, S.A.M.Z. and K.A.; writing-original draft preparation, S.A.M.Z.; writing-manuscript and editing, S.A.M.Z., A.A., F.A. and K.A.; validation, S.A.M.Z. and K.A.; supervision, M.R.S., K.A. All authors have read and agreed to the published version of the manuscript.

Funding: Special appreciation to the Ministry of Higher Education Malaysia for funding this research under the Long-term Research Grant Scheme (LRGS/1/2019/UPM/01/2/2): Sustainable short and medium to long-term strategies for managing bacterial panicle blight disease under climate-resilience rice production.

Institutional Review Board Statement: Not applicable.

Informed Consent Statement: Not applicable.

Data Availability Statement: All data is available in the main text.

Acknowledgments: S.A.M.Z. wishes to thank Universiti Putra Malaysia for the post-doctorate position.

Conflicts of Interest: The authors have declared no conflicts of interest.

\section{References}

1. Market Research Reports, Marketing Research Company, Business Research by MarketsandMarkets. Available online: www. marketsandmarkets.com (accessed on 1 July 2021).

2. Hassaan, M.A.; El Nemr, A. Pesticides pollution: Classifications, human health impact, extraction and treatment techniques. Egypt. J. Aquat. Res. 2020, 46, 207-220. [CrossRef]

3. Gyawali, K. Pesticide Uses and its Effects on Public Health and Environment. J. Health Promot. 2018, 6, 28-36. [CrossRef]

4. Aktar, M.W.; Sengupta, D.; Chowdhury, A. Impact of pesticides use in agriculture: Their benefits and hazards. Interdiscip. Toxicol. 2009, 2, 1-12. [CrossRef]

5. Fiol, D.F.; Terrile, M.C.; Frik, J.; Mesas, F.A.; Álvarez, V.A.; Casalongué, C.A. Nanotechnology in plants: Recent advances and challenges. J. Chem. Technol. Biotechnol. 2021, 96, 2095-2108. [CrossRef]

6. Ali, S.S.; Al-Tohamy, R.; Koutra, E.; Moawad, M.S.; Kornaros, M.; Mustafa, A.M.; Mahmoud, Y.A.-G.; Badr, A.; Osman, M.E.H.; Elsamahy, T.; et al. Nanobiotechnological advancements in agriculture and food industry: Applications, nanotoxicity, and future perspectives. Sci. Total Environ. 2021, 792, 148359. [CrossRef]

7. El-Moneim, D.A.; Dawood, M.F.A.; Moursi, Y.S.; Farghaly, A.A.; Afifi, M.; Sallam, A. Positive and negative effects of nanoparticles on agricultural crops. Nanotechnol. Environ. Eng. 2021, 6, 21. [CrossRef]

8. Nisha, R.S.; Anooj, E.S.; Rajendran, K.; Vallinayagam, S. A comprehensive review on regulatory invention of nanopesticides in Agricultural nano formulation and food system. J. Mol. Struct. 2021, 1239, 130517. [CrossRef]

9. Mustafa, I.F.; Hussein, M.Z.; Saifullah, B.; Idris, A.S.; Hilmi, N.H.Z.; Fakurazi, S. Synthesis of (Hexaconazole-Zinc/AluminumLayered Double Hydroxide Nanocomposite) Fungicide Nanodelivery System for Controlling Ganoderma Disease in Oil Palm. J. Agric. Food Chem. 2018, 2, 806-813. [CrossRef] [PubMed]

10. Saratale, R.G.; Saratale, G.D.; Shin, H.S.; Jacob, J.M.; Pugazhendhi, A.; Bhaisare, M.; Kumar, G. New insights on the green synthesis of metallic nanoparticles using plant and waste biomaterials: Current knowledge, their agricultural and environmental applications. Environ. Sci. Pollut. Res. 2018, 25, 10164-10183. [CrossRef] [PubMed]

11. Nanoscience and Nanotechnology News. 2021. Available online: www.Statnano.com (accessed on 15 July 2021).

12. Campos, E.V.R. Commercial nanoproducts available in world market and its economic viability. In Advances in Nano-Fertilizers and Nano-Pesticides in Agriculture, A Smart Delivery System for Crop Improvement; Woodhead Publishing Series in Food Science, Technology \& Nutrition; Woodhead Publishing: Sawston, UK, 2021; pp. 561-593.

13. Grillo, R.; Fraceto, L.F.; Amorim, M.J.B.; Scott-Fordsmand, J.J.; Schoonjans, R.; Chaudhry, Q. Ecotoxicological and regulatory aspects of environmental sustainability of nanopesticides. J. Hazard. Mater. 2021, 404, 124148. [CrossRef] 
14. Triadimefon Reregistration Eligibility Decision (RED) and Triadimenol Tolerance Reassessment and Risk Management Decision (TRED) Fact Sheet. Available online: https://www3.epa.gov/pesticides/chem_search/reg_action/reregistration/fs_UG-6 (accessed on 15 July 2021).

15. World Health Organization. The WHO Recommended Classification of Pesticides by Hazard and Guidelines to Classification. 2019. Available online: https://www.who.int/publications/i/item/9789240005662. (accessed on 15 July 2021).

16. International Union of Pure and Applied Chemistry (IUPAC), IUPAC Pesticides Properties Database. Available online: http: / / sitem.herts.ac.uk/aeru/iupac/index.htm (accessed on 15 July 2021).

17. European Commission Food Safety, EU Pesticides Database. Available online: https://ec.europa.eu/food/plants/pesticides/eupesticides-database_en (accessed on 15 July 2021).

18. National Pesticide Information Center. Available online: http:/ /npic.orst.edu/ (accessed on 15 July 2021).

19. ISO. Nanotechnologies-Vocabolary- Part 1: Core Terms 2015. Available online: https://www.iso.org/standard/68058.html (accessed on 15 July 2021).

20. Donaldson, K.; Stone, V.; Tran, C.L.; Kreyling, W.; Borm, P.J. Nanotoxicology. Occup. Environ. Med. 2004, 61, 727-728. [CrossRef] [PubMed]

21. Bahadar, H.; Maqbool, F.; Niaz, K.; Abdollahi, M. Toxicity of Nanoparticles and an Overview of Current Experimental Models. Iran Biomed J. 2016, 20, 1-11. [PubMed]

22. Farhatun, N.M.; Hussein, M.Z.; Yusof, N.A.; Idris, A.B.; Daim, L.D.J.; Sarian, M.N.; Rajab, N.F.; Ling, S.E.; Rashid, N.; Fakurazi, S. Cytoprotection, Genoprotection, and Dermal Exposure Assessment of Chitosan-Based Agronanofungicides. Pharmaceutics 2020, $12,497$.

23. Elsaesser, A.; Howard, C.V. Toxicology of nanoparticles. Adv. Drug Deliv. Rev. 2012, 64, 129-137. [CrossRef] [PubMed]

24. Chaud, M.; Souto, E.B.; Zielinska, A.; Severino, P.; Batain, F.; Oliveira-Junior, J.; Alves, T. Nanopesticides in Agriculture: Benefits and Challenge in Agricultural Productivity, Toxicological Risks to Human Health and Environment. Toxics 2021, 9, 131. [CrossRef]

25. Koba-Ucun, O.; Hanci, T.O.; Arslan-Alaton, I.; Arefi-Oskoui, S.; Khataee, A.; Kobya, M.; Orooji, Y. Toxicity of Zn-Fe Layered Double Hydroxide to Different Organisms in the Aquatic Environment. Molecules 2021, 26, 395. [CrossRef]

26. Jaehwan, J.J.; Kim, S.K.; Hong, J. Zn-Al Layered Double Hydroxide Thin Film Fabricated by the Sputtering Method and Aqueous Solution Treatment. Coatings 2020, 10, 669.

27. Karthikeyan, J.; Fjellvåg, H.; Bundli, S.; Sjåstad, A.O. Efficient Exfoliation of Layered Double Hydroxides; Effect of Cationic Ratio, Hydration State, Anions and Their Orientations. Materials 2021, 14, 346. [CrossRef]

28. Rives, V.; del Arco, M.; Martín, C. Intercalation of drugs in layered double hydroxides and their controlled release: A review. Appl. Clay Sci. 2014, 88, 239-269. [CrossRef]

29. Li, F.; Zhang, L.; Evans, D.E.; Forano, C.; Duan, X. Structure and thermal evaluation of Mg-Al-layered double hydroxide containing interlayer organic glyphosate anions. Thermochim. Acta 2004, 424, 15-23. [CrossRef]

30. Xu, Z.P.; Lu, G.Q. Layered double hydroxide nanomaterials as potential cellular drug delivery agents. Pure Appl. Chem. 2006, 78, 1771-1779. [CrossRef]

31. Ladewig, K.; Niebert, M.; Xu, Z.P.; Gray, P.P.; Lu, G.Q. Efficient siRNA delivery to mammalian cells using layered double hydroxide nanoparticles. Biomaterials 2010, 31, 1821-1829. [CrossRef]

32. Mohsin, S.M.M.; Hussein, M.Z.; Sarijo, S.H.; Fakurazi, S.; Arulselvan, P.; Hin, T.Y.Y. Nanolayered composite with enhanced ultraviolet ray absorption properties from simultaneous intercalation of sunscreen molecules. Int. J. Nanomed. 2018, 13, 6359-6374. [CrossRef]

33. Fan, G.; Li, F.; Evans, D.G.; Duan, X. Catalytic applications of layered double hydroxides: Recent advances and perspectives. Chem Soc Rev. 2014, 43, 7040-7066. [CrossRef] [PubMed]

34. Wanga, L.; Zhua, Z.; Wang, F.; Qi, Y.; Zhang, W.; Wang, C. State-of-the-art and prospects of Zn-containing layered double hydroxides (Zn-LDH)-based materials for photocatalytic water remediation. Chemosphere 2021, 278, 130367. [CrossRef]

35. Kulandaivalu, S.; Azman, N.H.N.; Sulaiman, Y. Advances in Layered Double Hydroxide/Carbon Nanocomposites Containing $\mathrm{Ni}^{2+}$ and $\mathrm{Co}^{2+/ 3+}$ for Supercapacitors. Front. Mater. 2020, 7, 147. [CrossRef]

36. Kesavan, S.; Phumelele, P.; Marindade, K.; Mudaly, B.P. Layered double hydroxides: An advanced encapsulation and delivery system for cosmetic ingredients-an overview. Appl. Clay Sci. 2020, 199, 105868. [CrossRef]

37. Bi, X.; Zhang, H.; Dou, L. Layered Double Hydroxide-Based Nanocarriers for Drug Delivery. Pharmaceutics 2014, 6, $298-332$. [CrossRef]

38. Wena, J.; Yang, K.; Huanga, J.; Sun, S. Recent advances in LDH-based nanosystems for cancer therapy. Mat. Des. 2021, 198, 109298. [CrossRef]

39. Bullo, S.; El Zowalaty, M.E.; Arulselvan, P.; Fakurazi, S.; Webster, T.J.; Geilich, B.M.; Hussein, M.Z. Synthesis, characterization, and efficacy of antituberculosis isoniazid zinc aluminum-layered double hydroxide based nanocomposites. Int. J. Nanomed. 2016, $11,3225-3237$.

40. Gu, N.; Gao, J.; Wang, K.; Dong, W.; Ma, Y. Microcystis aeruginosa inhibition by Zn-Fe-LDHs as photocatalyst under visible light. J. Taiwan Inst. Chem. Eng. 2016, 64, 89-195. [CrossRef]

41. Ariga, K.; Kunitake, T. Supramolecular Chemistry: Fundamentals and Applications, 1st ed.; Springer: Berlin, Germany, 2006; pp. 1-208. [CrossRef]

42. Steed, J.W.; Atwood, J.L. Supramolecular Chemistry, 2nd ed.; Wiley: Hoboken, NJ, USA, 2009; pp. 105-222. [CrossRef] 
43. Whitesides, G.M.; Mathias, J.P.; Seto, C.T. Molecular self-assembly and nanochemistry: A chemical strategy for the synthesis of nanostructures. Science 1991, 254, 1312-1319. [CrossRef]

44. Wenz, G. An Overview of Host-Guest Chemistry and its Application to Nonsteroidal Anti-Inflammatory Drugs. Clin. Drug Investig. 2000, 19, 21-25. [CrossRef]

45. Yang, H.; Xiong, C.; Liu, A.; Li, W. The effect of layered double hydroxides intercalated with vitamin B3 on the mechanical properties, hydration and pore structure of cement-based materials. Mater. Lett. 2021, 300, 130228. [CrossRef]

46. Djebbi, M.A.; Elabed, A.; Bouaziz, Z.; Sadiki, M.; Elabed, S.; Namour, P.; Jaffrezic-Renault, N.; Amara, A.B.H. Delivery system for berberine chloride based on the nanocarrier ZnAl-layered double hydroxide: Physicochemical characterization, release behavior and evaluation of anti-bacterial potential. Int. J. Pharm. 2016, 515, 422-430. [CrossRef] [PubMed]

47. Meyn, M.; Benecke, K.; Lagally, G. Anion-exchange reactions of layered double hydroxides. Inorg. Chem. 1990, 29 , 5201-5207. [CrossRef]

48. Khan, A.I.; Ragavan, A.; Fong, B.; Markland, C.; O’Brien, M.; Dunbar, T.G.; Williams, G.R.; O’Hare, D. Recent developments in the use of layered double hydroxides as host materials for the storage and triggered release of functional anions. Ind. Eng. Chem. Res. 2009, 48, 10196-10205. [CrossRef]

49. Cardoso, L.P.; Valim, J.B. Competition between three organic anions during regeneration process of calcined LDH. J. Phys. Chem. Solids 2004, 65, 481-485. [CrossRef]

50. Muda, Z.; Hashim, N.; Md Isa, I.; Mustafar, S.; Bakar, S.A.; Mamat, M.; Hussein, M.Z. Release behavior of dichlorprop from Zn/Al-LDH-dichlorprop nanocomposite into chlo-ride, carbonate and phosphate solutions. J. Teknol. Sci. Eng. $2019,81$. [CrossRef]

51. Hixson, A.W.; Crowell, J.H. Dependence of reaction velocity upon surface and agitation (I) theoretical consideration. Ind. Eng. Chem. 1931, 23, 923-931. [CrossRef]

52. Korsmeyer, R.W.; Peppas, N.A. Solute and penetrant diffusion in swellable polymers. III. Drug release from glassy poly(HEMAco-NVP) copolymers. J. Cont. Release 1984, 1, 89-98. [CrossRef]

53. Baker, R.W.; Lonsdale, H.K. Controlled Release: Mechanisms and Rates. In in Controlled Release of Biologically Active Agents; Tanquary, A.C., Lacey, R.E., Eds.; Plenum Press: New York, NY, USA, 1974; Volume 181, pp. 581-624.

54. Hopfenberg, H.B. Controlled Release Polymeric Formulations, 1st ed.; Paul, D.R., Haris, F.W., Eds.; American Chemical Society: Washington, DC, USA, 1976; Symposium Series 33.

55. Slideshare Kinetic Models. Available online: https://www.slideshare.net/RiteshGhate/kinetic-models (accessed on 5 October 2021).

56. Sorensen, B.; Spazzafumo, G. Fuel Cells. In Hydrogen and Fuel Cells, 3rd ed.; (Emerging Technologies and Application); Academic Press: Cambridge, MA, USA, 2018; pp. 107-220. [CrossRef]

57. Wikipedia. Weilbull Distribution. Available online: https://en.wikipedia.org/wiki/Weibull_distribution (accessed on 5 October 2021).

58. Baby, R.; Bullo, S.; Hussein, M.Z. Palm Kernel Shell as an effective adsorbent for the treatment of heavy metal contaminated water. Sci. Rep. 2019, 9, 18955. [CrossRef]

59. Mircioiu, C.; Voicu, V.; Anuta, V.; Tudose, A.; Celia, C.; Paolino, D.; Fresta, M.; Sandulovici, R.; Mircioiu, I. Mathematical Modeling of Release Kinetics from Supramolecular Drug Delivery Systems. Pharmaceutics 2019, 11, 140. [CrossRef] [PubMed]

60. Paarakh, M.P.; Jose, P.A.; Setty, C.M.; Christoper, G.V.P. Release Kinetics-Concepts and Applications. Int. J. Pharm. Res. Tech. 2018, 8, 12-20.

61. Muda, Z.; Hashim, N.; Isa, I.M.; Bakar, S.A.; Ali, N.M.; Hussein, M.Z.; Mamat, M.; Sidik, S.M. Synthesis and characterization of mesoporous zinc layered hydroxide-isoprocarb nanocomposite. J. Saudi Chem. Soc. 2019, 23, 486-493. [CrossRef]

62. Muda, Z.; Hashim, N.; Isa, I.M.; Ali, N.M.; Bakar, S.A.; Mamat, M.; Hussein, M.Z.; Bakar, N.A.; Mahamod, W.R.W. Synthesis and characterization of carbamate insecticideintercalated zinc layered hydroxide modified with sodium dodecyl sulphate. IOP Conf. Ser. Mater. Sci. Eng. 2018, 440, 12003. [CrossRef]

63. Hashim, N.; Muda, Z.; Isa, I.M.; Ali, N.M.; Bakar, S.A.; Hussein, M.Z. The effect of ion exchange and co-precipitation methods on the intercalation of 3-(4-methoxyphenyl)propionic acid into layered zinc hydroxide nitrate. J. Porous Mater. 2017, 1, 1-10. [CrossRef]

64. Sharif, S.N.M.; Hashim, N.; Isa, I.M.; Bakar, S.A.; Saidin, M.I.; Ahmad, M.S.; Mamat, M.; Hussein, M.Z. The influence of chitosan coating on the controlled release behaviour of zinc/aluminium-layered double hydroxide-quinclorac composite. Mater. Chem. Phys. 2020, 251, 123076. [CrossRef]

65. Hussein, M.Z.; Rahman, N.S.S.A.; Sarijo, S.H.; Zainal, Z. Synthesis of a monophasic nanohybrid for a controlled release formulation of two active agents simultaneously. Appl. Clay Sci. 2012, 58, 60-66. [CrossRef]

66. Foad, N.S.I.M.; Dzulkifli, N.N.; Abdullah, A.; Jadam, M.L.; Ghazali, S.A.I.S.M. Synthesis and Characterisation of Zinc Layered Hydroxide Intercalated with 2-Methyl-4- Chlorophenoxyacetic Acid and its Controlled Release Application. ASM Sci. J. 2021, 15, 1-10. [CrossRef]

67. Liu, J.; Wang, J.; Zhang, X. Intercalation, characterization and release behavior of imidacloprid into layered hydroxide salts by coupling of (3-glycidyloxypropyl) trimethoxysilane. Colloids Surf. A Physicochem. Eng. Asp. 2018, 553, 42-49. [CrossRef]

68. Muda, Z.; Hashim, N.; Md Isa, I.; Mustafar, S.; Bakar, S.A.; Mamat, M.; Hussein, M.Z. Adsolubilisation of thiacloprid pesticide into the layered zinc hydroxide salt intercalated with dodecyl sulphate, for controlled release formulation. Mater. Res. Innov. 2020, 24, 279-288. [CrossRef] 
69. Liu, J.; Zhang, X.; Zhang, Y. Preparation and release behavior of chlorpyrifos adsolubilized into layered zinc hydroxide nitrate intercalated with dodecylbenzenesulfonate. ACS Appl. Mater. Interfaces 2015, 7, 11180-11188. [CrossRef]

70. Tang, L.P.; Cheng, H.M.; Cui, S.M.; Wang, X.R.; Song, L.Y.; Zhou, W.; Li, S.J. DL-mandelic acid intercalated Zn-Al layered double hydroxide: A novel antimicrobial layered material. Colloids Surf. B Biointerfaces 2018, 165, 111-117. [CrossRef] [PubMed]

71. Bashi, A.M.; Hussein, M.Z.; Zainal, Z.; Rahmani, M.; Tichit, D. Simultaneous intercalation and release of 2,4-dichloro- and 4-chloro-phenoxy acetates into Zn/Al layered double hydroxide. Arab. J. Chem. 2016, 9, S1457-S1463. [CrossRef]

72. Phuong, N.T.K.; Ha, H.N.N.; Dieu, N.T.P.; Huy, B.T. Herbicide/Zn-Al-layered double hydroxide hybrid composite: Synthesis and slow/controlled release properties. Environ. Sci. Pollut. Res. 2017, 24, 19386-19392. [CrossRef]

73. Malafatti, J.O.D.; Bernardo, M.P.; Moreira, F.K.V.; Ciol, H.; Inada, N.M.; Mattoso, L.H.C.; Paris, E.C. Electrospun poly(lactic acid) nanofibers loaded with silver sulfadiazine/[Mg-Al]-layered double hydroxide as an antimicrobial wound dressing. Polym. Adv. Technol. 2020, 31, 1377-1387. [CrossRef]

74. Sharif, S.N.M.; Hashim, N.; Isa, I.M.; Ali, N.M.; Bakar, S.A.; Hussein, M.Z.; Mamat, M.; Bakar, N.A.; Mahamod, W.R.W. Preparation and characterisation of novel paddy cultivation herbicide nanocomposite from zinc/aluminium layered double hydroxide and quinclorac anion. Mater. Res. Innov. 2019, 23, 260-265. [CrossRef]

75. Mustafa, I.F.; Hussein, M.Z.; Seman, I.A.; Hilmi, N.H.Z.; Fakurazi, S. Synthesis of Dazomet-Zinc/Aluminum-Layered Double Hydroxide Nanocomposite and Its Phytotoxicity Effect on Oil Palm Seed Growth. ACS Sustain. Chem. Eng. 2018, 6, 16064-16072. [CrossRef]

76. Morales-Irigoyen, E.E.; de las Mercedes Gómez-y-Gómez, Y.; Flores-Moreno, J.L.; Franco-Hernández, M.O. A bionanohybrid ZnAl-NADS ecological pesticide as a treatment for soft rot disease in potato (Solanum tuberosum L.). Environ. Sci. Pollut. Res. 2018, 25, 21430-21439. [CrossRef]

77. El-Shahawy, A.A.G.; Abo El-Ela, F.I.; Mohamed, N.A.; Eldine, Z.E.; El Rouby, W.M.A. Synthesis and evaluation of layered double hydroxide/doxycycline and cobalt ferrite/chitosan nanohybrid efficacy on gram positive and gram negative bacteria. Mater. Sci. Eng. C Mater Biol Appl. 2018, 91, 361-371. [CrossRef] [PubMed]

78. Cruz, A.S.; Flores, J.; Guerra, R.; Felipe, C.; Lima, E. Organic biocides hosted in layered double hydroxides: Enhancing antimicrobial activity: Hybrid organic-inorganic biocides. Open Chem. 2018, 16, 163-169. [CrossRef]

79. Gao, Y.; Zhou, Z.; Chen, X.; Tian, Y.; Li, Y.; Wang, H.; Li, X.; Yua, X.; Cao, Y. Controlled release of herbicides by 2,4-D-, MCPA-, and bromoxynil-intercalated hydrotalcite nanosheets. Green Chem. 2021, 23, 4560-4566. [CrossRef]

80. Zhao, J.; Fu, X.; Zhang, S.; Hou, W. Water dispersible avermectin-layered double hydroxide nanocomposites modified with sodium dodecyl sulfate. Appl. Clay Sci. 2011, 51, 460-466, 28. [CrossRef]

81. Fahim, H.A.; Rouby, W.M.A.E.; El-Gendy, A.O.; Khairalla, A.S.; Naguib, I.A.; Farghali, A.A. Enhancement of the productivity of the potent bacteriocin avicin A and improvement of its stability using nanotechnology approaches. Sci. Rep. 2017, 7, 10604. [CrossRef]

82. Mishra, G.; Dash, B.; Pandey, S. Effect of molecular dimension on gallery height, release kinetics and antibacterial activity of $\mathrm{Zn}-\mathrm{Al}$ layered double hydroxide (LDH) encapsulated with benzoate and its derivatives. Appl. Clay Sci. 2019, 181, 105230. [CrossRef]

83. Sharif, S.N.M.; Hashim, N.; Isa, I.M.; Bakar, S.A.; Saidin, M.I.; Ahmad, M.S.; Mamat, M.; Hussein, M.Z.; Zainul, R. Polymeric Nanocomposite-Based Herbicide of Carboxymethyl Cellulose Coated-Zinc/Aluminium Layered Double Hydroxide-Quinclorac: A Controlled Release Purpose for Agrochemicals. J. Polym. Environ. 2021, 29, 1817-1834. [CrossRef]

84. Gohi, B.F.C.A.; Zeng, H.-Y.; Xu, S.; Zou, K.-M.; Liu, B.; Huang, X.L.; Cao, X.-J. Optimization of znal/chitosan supra-nano hybrid preparation as efficient antibacterial material. Int. J. Molecul. Sci. 2019, 20, 5705. [CrossRef]

85. Liu, J.X.; Ren, J.H.; Zhao, Q.; Shi, T.J.; Liu, Z.F.; Luo, Z.; Zhang, X.G. Preparation and characterization of chlorpyrifos/cyclodextrin complex intercalation into ZnAl-layered double hydroxide. Wuli Huaxue Xuebao/Acta Phys.—Chim. Sin. 2016, 32, 558-564. [CrossRef]

86. Bugatti, V.; Vertuccio, L.; Zara, S.; Fancello, F.; Scanu, B.; Gorrasi, G. Green pesticides based on cinnamate anion incorporated in layered double hydroxides and dispersed in pectin matrix. Carbohydr. Polym. 2019, 209, 356-362. [CrossRef]

87. Mishra, G.; Dash, B.; Sethi, D.; Pandey, S.; Mishra, B.K. Orientation of Organic Anions in Zn-Al Layered Double Hydroxides with Enhanced Antibacterial Property. Environ. Eng. Sci. 2017, 34, 516-527. [CrossRef]

88. Zhang, X.; Liu, J.; Hou, W.; Tong, J.; Ren, L.; Sun, G.; Sun, Y. Preparation and Properties of Pesticide/Cyclodextrin Complex Intercalated into ZnAl-Layered Double Hydroxide. Ind. Eng. Chem. Res. 2016, 55, 1550-1558. [CrossRef]

89. Lobo-Sánchez, M.; Nájera-Meléndez, G.; Luna, G.; Segura-Pérez, V.; Rivera, J.A.; Fetter, G. ZnAl layered double hydroxides impregnated with eucalyptus oil as efficient hybrid materials against multi-resistant bacteria. Appl. Clay Sci. 2018, 153, 61-69. [CrossRef]

90. Hussein, M.Z.B.; Hashim, N.; Yahaya, A.H.; Zainal, Z. Controlled release formulation of agrochemical pesticide based on 4-(2,4 dichlorophenoxy)butyrate nanohybrid. J. Nanosci. Nanotechnol. 2009, 9, 2140-2147. [CrossRef]

91. Bohari, F.L.; Sufian, F.I.; Ghazali, S.A.I.S.M.; Dzulkifli, N.N. The synthesis and characterization of layered hydroxide salt interleaved with 4-chlorophenoxyacetic acid and its control release study as herbicide. AIP Conf. Proc. 2021, $2332,80001$. [CrossRef] 
92. Kuznetsova, A.; Domingues, P.M.; Silva, T.; Almeida, A.; Zheludkevich, M.L.; Tedim, J.; Ferreira, M.G.S.; Cunha, A. Antimicrobial activity of 2-mercaptobenzothiazole released from environmentally friendly nanostructured layered double hydroxides. J. Appl. Microbiol. 2017, 122, 1207-1218. [CrossRef]

93. Bruna, F.; Celis, R.; Pavlovic, I.; Barriga, C.; Cornejo, J.; Ulibarri, M.A. Layered double hydroxides as adsorbents and carriers of the herbicide (4-chloro-2-methylphenoxy)acetic acid (MCPA): Systems Mg-Al, Mg-Fe and Mg-Al-Fe. J. Hazard. Mater. 2009, 168, 1476-1481. [CrossRef]

94. Nadiminti, P.P.; Sharma, H.; Kada, S.R.; Pfeffer, F.M.; O’Dell, L.A.; Cahill, D.M. Use of Mg-Al Nanoclay as an Efficient Vehicle for the Delivery of the Herbicide 2,4-Dichlorophenoxyacetic Acid. ACS Sustain. Chem. Eng. 2019, 7, 10962-10970. [CrossRef]

95. Rebitski, E.P.; Darder, M.; Aranda, P. Layered double hydroxide/sepiolite hybrid nanoarchitectures for the controlled release of herbicides. Beilstein J. Nanotechnol. 2019, 10, 1679-1690. [CrossRef] [PubMed]

96. Touloupakis, E.; Margelou, A.; Ghanotakis, D.F. Intercalation of the herbicide atrazine in layered double hydroxides for controlledrelease applications. Pest Manag. Sci. 2011, 67, 837-841. [CrossRef] [PubMed]

97. Kutlu, B.; Schröttner, P.; Leuteritz, A.; Boldt, R.; Jacobs, E.; Heinrich, G. Preparation of melt-spun antimicrobially modified LDH/polyolefin nanocomposite fibers. Mater. Sci. Eng. C 2014, 41, 8-16. [CrossRef]

98. Park, M.; Lee, C.I.; Seo, Y.J.; Woo, S.R.; Shin, D.; Choi, J. Hybridization of the natural antibiotic, cinnamic acid, with layered double hydroxides (LDH) as green pesticide. Environ. Sci. Pollut. Res. 2010, 17, 203-209. [CrossRef] [PubMed]

99. Zhenlan, Q.; Heng, Y.; Bin, Z.; Wanguo, H. Synthesis and release behavior of bactericides intercalated Mg-Al layered double hydroxides. Colloids Surf. A Physicochem. Eng. Asp. 2009, 348, 164-169. [CrossRef]

100. Khatem, R.; Celis, R.; Hermosín, M.C. Cationic and anionic clay nanoformulations of imazamox for minimizing environmental risk. Appl. Clay Sci. 2019, 168, 106-115. [CrossRef]

101. López-Cabeza, R.; Cornejo, J.; Celis, R. Evaluation of an organo-layered double hydroxide and two organic residues as amendments to immobilize metalaxyl enantiomers in soils: A comparative study. J. Environ. Manag. 2016, 181, 135-145. [CrossRef] [PubMed]

102. Barnabas, M.J.; Parambadath, S.; Nagappan, S.; Ha, C.-S. Sulfamerazine Schiff-base complex intercalated layered double hydroxide: Synthesis, characterization, and antimicrobial activity. Heliyon 2019, 5, e01521. [CrossRef] [PubMed]

103. Liao, X.; Li, B.; Zou, R.; Dai, Y.; Xie, S.; Yuan, B. Biodegradation of antibiotic ciprofloxacin: Pathways, influential factors, and bacterial community structure. Environ. Sci. Pollut. Res. 2016, 23, 7911-7918. [CrossRef]

104. Steenackers, W.; El-Houari, I.; Baekelandt, A.; Witvrouw, K.; Dhondt, S.; Leroux, O.; Gonzalez, N.; Corneillie, S.; Cesarino, I.; Inzé, D. cis-Cinnamic acid is a natural plant growth-promoting compound. J. Exp. Bot. 2019, 70, 6293-6304. [CrossRef]

105. Van Overbeek, J.; Blondeau, R.; Horne, V. Trans-cinnamic acid is antiauxin, antagonizes the growth-promoting effect of auxins in the pea stem section test. Am. J. Bot. 1951, 38, 589-595. [CrossRef]

106. Recent Additions for 2006. Available online: https://cfpub.epa.gov/ncea/cfm/archive_whatnew_display.cfm?year=2006 (accessed on 15 July 2021).

107. European Food Safety Authority. Peer review of the pesticide risk assessment of the active substance imazamox. EFSA J. 2016, 2, 4432. [CrossRef]

108. Asiabi, H.; Yamini, Y. Shamsayei, M. Using cobalt/chromium layered double hydroxide nano-sheets as a novel packed in-tube solid phase microextraction sorbent for facile extraction of acidic pesticides from water samples. J. Chem. 2018, 42, 9935-9944.

109. Gutner-Hoch, E.; Martins, R.; Maia, F.; Oliveira, T.; Shpigel, M.; Weis, M.; Tedim, J.; Benayahu, Y. Toxicity of engineered microand nanomaterials with antifouling properties to the brine shrimp Artemia salina and embryonic stages of the sea urchin Paracentrotus lividus. Environ. Pollut. 2019, 251, 530-537. [CrossRef] [PubMed]

110. Majoni, S.; Hossenlopp, J.M. Controlled release kinetics in hydroxy double salts: Effect of host anion structure. Adv. Phys. Chem. 2014, 2014, 710487. [CrossRef]

111. Ragavan, A.; Khan, A.I.; O'Hare, D. Selective intercalation of chlorophenoxyacetates into the layered double hydroxide [LiAl2(OH)6]Cl·xH2O. J. Mater. Chem. 2006, 2, 4155-4159. [CrossRef] 